\title{
Nuevas mitologías urbanas
}

\author{
Grupo de Investigación "La aventura de viajar y sus escrituras" \\ Universidad Complutense de Madrid \\ gilave@filol.ucm.es
}

\begin{abstract}
Resumen
Las ciudades, históricamente, han acogido en su interior espacios sagrados, dedicados al culto $y$, en muchas ocasiones, relacionados con la fundación mítica y el pasado legendario de la urbe. En la ciudad posmoderna esos lugares sagrados tradicionales han sido sustituidos por otros nuevos templos urbanos, en función de los nuevos mitos generados por la sociedad contemporánea o la historia reciente.
\end{abstract}

Palabras clave: espacio urbano, nuevos templos urbanos, ciudad y literatura.

Title: New Urban Mythologies

Abstract

Cities have historically embraced sacred places, dedicated to the cult and related in many cases to the foundational myth and legendary past of the city. In postmodern city these traditional holy places have been replaced by new urban temples, according to the new myths generated by contemporary society and recent history.

Keywords: urban space, new urban temples, city and literature.

\section{Índice}

1. Lugares históricos, lugares míticos

2. El espacio cerrado del gueto

3. El estadio: un icono moderno

4. Teatros y museos que cambian de signo: la Bastilla y el Louvre

5. El Louvre y la Bastilla: de los edificios a la mitificación de los lugares

\section{Lugares históricos, lugares míticos}

Eugenia POPEANGA CHELARU

La ciudad, como todo espacio delimitado, se organiza en torno a un punto nuclear marcado por construcciones (monumenta) en honor a un dios o a un héroe épico. Hay ciudades proyectadas a partir de una tumba fundacional, como sería el caso, en cierto modo, de Jerusalén o Santiago de Compostela, por lo mismo que hay otras que llevan el marchamo de su epónimo, bien como fundador (Roma, Constantinopla), bien como personaje consagrado (Alejandría, Cesarea, Atenas, Zaragoza, San Francisco o Adrianópolis). En la medida en que nos es conocida la etimología del topónimo, vemos otras ciudades que reflejan una característica: Montreal, Königsberg, 
Villaviciosa, Villarreal, Belgrado, Salzburg, Alcalá, Guadalajara, etc. Hay ciudades también que, en la cima de una de sus colinas, han erigido un monumento a su héroe emblemático.

Los templos, espacios sagrados, ritualizan el mito fundacional, manteniendo intactos los elementos básicos. Debido, empero, a las características del paisaje urbano, conviven con espacios profanos, donde se emprenden cotidianamente ritos de régimen social, tales como los actos teatrales, musicales o deportivos, rituales en los que se consagran nuevos héroes y consolidan los ya reconocidos, que engrosan el elenco legendario, forjando a veces el acervo mítico. Así, los dioses comparten su gloria y devoción con los campeones deportivos, los autores famosos y los artistas triunfadores (de cine, de teatro o musicales). El templo délfico en honor de Apolo, erigido en la falda del Parnaso, tiene a su lado un importante estadio de la Antigüedad. Por su parte, la ladera de la Acrópolis se articula en las gradas conducentes al Partenón.

En el mundo medieval, dominado por las doctrinas del "Libro Sagrado", que propaga los fundamentos de la mitología judeocristiana, el espectáculo teatral se representa en las iglesias, como una diversión de asunto sacro; cuando más tarde se traslade a un espacio profano, lo hará en el atrio o en la plaza aledaña al propio templo. Torneos y certámenes diversos, si bien dejan de lado lo sagrado, no por ello abandonan los rituales, aquí conforme al código caballeresco, destacando el honor, el amor o la pericia artística, en cuyo terreno florecen y se consagran nuevos héroes.

Vemos, pues, cómo la configuración del espacio urbano europeo incorpora elementos con que se ritualizan mitos fundacionales, propiciando el surgimiento y desarrollo de nuevos héroes, capaces de llevar a cabo hazañas que pasen a la leyenda, o incluso, como queda dicho, se conviertan en mitos. Esa capacidad del espacio urbano para organizarse en virtud de un hito mítico y para dar origen a otros mitos, permanece a lo largo de su historia. La ciudad no moderna (antigua, medieval, renacentista...), sin embargo, delimita con obvia precisión los espacios sagrados y profanos, mientras que la moderna se configura en forma diferente. Si el núcleo sagrado se mantiene, ha perdido, no obstante, su antiguo predicamento. El nuevo núcleo urbano constituye el centro neurálgico del comercio y el espectáculo. Los héroes modernos son los grandes banqueros y artistas destacados, o en época reciente, si no actual, el militar envuelto en uniforme que exhibe su aureola de triunfador marcial. Así, tenemos plazas por doquier que conmemoran episodios bélicos: Trafalgar Square, Plaza de la Independencia o del Dos de Mayo. Monumentos tales como arcos de triunfo (si bien son calcos de la antigua Roma) tienen significado semejante, emblemáticamente concebidos.

Dentro de la ciudad moderna se asienta otra ciudad, profana en apariencia, en que los ritos iniciáticos de los futuros héroes piden 
ímprobo esfuerzo en tiempo prolongado. Las nuevas catedrales son aquí la City londinense o el Wall Street neoyorquino. En estos núcleos de la ciudad moderna, unos rinden culto a los dioses Mercurio y Plutón, así como otros a las musas, en honor de las cuales se levantan templos como el Metropolitan Opera House de Nueva York, el Covent Garden Iondinense, la Ópera de París, la Scala de Milán, o la Staatsoper de Viena o de Berlín. Los directores y cantantes más famosos se convierten en dioses para un público que les rinde homenaje y pleitesía con ardiente fervor en cada noche de sus actuaciones. A la banca y al reino del espectáculo se añade hoy día un nuevo templo que amalgama ambos mundos. El gran almacén y el centro comercial son los nuevos espacios que concitan acordes los sentidos del cliente consumista - vista, oído, olfato, gusto y tacto- en una concertada sinestesia, que lo entrega, obsecuente y complacido, al culto fervoroso de Mercurio.

A esto se añade un nuevo ritual, que plasma y resucita ciertos otros durante varios siglos olvidados. A finales del siglo XIX los ingleses ponen en marcha el fútbol, un juego de orden competitivo, con lo cual el estadio deportivo, tras varios siglos en hibernación, vuelve a surgir como templo en que se desenvuelven rituales de este tipo. De entre los numerosos deportes practicados en la ciudad moderna, es el "balompedestre" el que se lleva la palma en cuanto a sus devotos seguidores. El estadio es la nueva catedral en cuyos actos participan los escasos oficiantes y los numerosos feligreses en calidad de espectadores. El siglo $\mathrm{XX}$ ha forjado toda una red de templos de este tipo, en que los oficiantes son visibles o virtuales, aunque siempre (como en el comercio) funcionalmente eficientes a la hora de cautivar a la masa devota.

De la época en que el palacio real, espacio profano, compite en rango con la catedral, espacio religioso, centros gravitatorios del poder temporal y espiritual, pasamos a la era de las grandes plazas que delatan el régimen republicano, en que ha periclitado la realeza y el poder eclesiástico ha perdido vigor. La Gran Asamblea Nacional de Francia reemplaza en París el influjo del palacio del Louvre. El nuevo edificio pasa a ser la sede en que se oficia el rito del poder, en tanto que el viejo palacio se convierte en catedral del arte. La Revolución Francesa marca el inicio de la época moderna; el trazado urbanístico del barón Georges-Eugène Haussmann (ya concebido en el siglo IV a.C. por Dinócrates de Rodas) rompe la proyección circunsagrada en torno a Notre Dame, y sobre el tablero ajedrecístico del ensanche parisién asienta los nuevos templos de la banca, la ópera y los grandes almacenes. La Revolución Rusa del año 1917 consagra en San Petersburgo-Leningrado el muelle donde estaba atracado el acorazado Potemkin. Con la muerte de Lenin y la colocación de su mausoleo en la Plaza Roja moscovita, ésta cobra un carácter sagrado al convertirse en lugar de peregrinación. 
Pueblan el mundo urbano nuevos mitos, hermanados los políticos y los del espectáculo. Tenemos un Caruso y una Pavlova. Los comienzos del cine $y$, sobre todo, el paso del mudo al sonoro, generan una pujante mitología con sus templos en los que hasta hoy en día se oficia su ritual. La ciudad de Hollywood es toda una almáciga de nuevas deidades que, en virtud de la industria cinematográfica, realizan hazañas prodigiosas y se vuelven sujetos de leyenda que arrastran hacia sí a innúmeros devotos. La ciudad moderna gravita en torno a estos lugares nutridos por la exuberante cosecha de los monstruos sagrados que genera, sin olvidar los ritos oficiados en su honor por obra de sus fieles entusiastas.

Lejos estamos, evidentemente, de los arcaicos ritos fundacionales de ciudades; asistimos, en cambio, al surgimiento de nuevas mitologías urbanas, nacidas al socaire de los templos de reciente creación que comentamos, templos todos de índole profana. El Ilamado "cuarto poder", los medios de comunicación -la prensa en un comienzo $\mathrm{y}$, en la ciudad postmoderna, la radio $\mathrm{y}$, más aún, la televisión-, son los propagadores de esos mitos. Lo que nace en los templos antedichos se convierte en leyenda, y las hazañas de los nuevos héroes se difunden con rápida eficacia. En el prólogo a la primera edición de Mitologías, Roland Barthes afirma que "el mito es lenguaje". En el ensayo final de dicha obra, completa la anterior definición:

El mito no se define por el objeto de su mensaje, sino por la forma en que se lo propicia; sus límites son formales, no sustanciales. Entonces, ¿todo puede ser un mito? Sí, yo creo que sí, porque el universo es infinitamente sugestivo. Cada objeto del mundo puede pasar de una existencia cerrada, muda, a un estado oral, abierto a la apropiación de la sociedad, pues ninguna ley, natural o no, impide hablar de las cosas. (Barthes 1980: 199)

Obviando la interpretación de mitos primordiales, Barthes se decanta por la historicidad del mito, su "fundamento histórico" (1980: 200). Entendemos por ello que los mitos nacen en un momento dado, y acaso morirán dando paso a otros nuevos. Todo discurso es susceptible de encerrar y transmitir un mito, se trate de un discurso literario, o bien iconográfico. En el mundo moderno, los llamados mass media juegan un papel esencial para la mitificación y desmitificación de lugares.

En los momentos históricos de gran convulsión social y política, la ciudad desempeña un papel importante. El incendio de 1933 en el Reichstag de Berlín marca el comienzo de una grave crisis, como es la dictadura hitleriana, que conducirá a Europa a unas campañas de terror y muerte. La revolución soviética (con sus lugares emblemáticos) es un detonador de un cambio histórico que, junto con 
la I Guerra Mundial, hace redistribuir el mapa europeo. Lugares hay que, a modo de matrices revulsivas, gestan acontecimientos devastadores que, al ser protagonistas de unos hechos, proyectan una larga sombra mítica que perdura en forma de discurso literario. El muro de Berlín, telón de acero de la guerra fría que separaba a dos Europas, es un ejemplo claro del poder que reviste un elemento urbano artificial al servicio de un régimen dictatorial, que representa privación de libertad, terror y muerte. Su construcción, su función ominosa y las tragedias que ha provocado, han sido objeto de una fecunda producción literaria y fílmica, que lo ha convertido en lugar mítico de connotaciones negativas. Franquear el muro -la frontera prohibida- conlleva, si no la muerte, unas penosas pruebas iniciáticas, tan sólo superadas por unos pocos privilegiados. Las historias contadas sobre el paso del famoso "Punto Charly" dan fe de la existencia de una zona infernal conducente a la muerte o a la libertad. La destrucción del muro en noviembre de 1989 y la pérdida de su carga mítica con el reparto y venta de sus despojos como souvenirs turísticos, deja una huella amarga en la memoria de quienes lo han vivido y padecido. A la literatura corresponde dar testimonio de todo aquello, dejando a la postmodernidad que tome nota en el acervo de la Wikipedia, libre de toda carga mitológica.

En la línea de lugares históricos que sufren un proceso de mitificación y ulterior desmitificación, se halla una de las ciudades europeas más afectadas de cambios urbanísticos. La moderna Bucarest (de la anterior poseemos escasos testimonios), se organiza en torno a una avenida con nombre de victoria bélica. Su desarrollo urbano es un tanto caótico, con un núcleo de forma caprichosa que semeja la de un árbol frondoso cuyas raíces se asentasen en la plaza donde se erige la mole de la Universidad bucarestina. Calles pobladas de vegetación, casas dotadas de amplios jardines, palacetes avecindados con modestas edificaciones, entre las que a las veces se levanta un bloque de tres o cuatro plantas y hechura modernista, dan la impresión de un vasto poblachón, sobre todo en ciertos sectores. Lejana de allí queda, alzada sobre una colina, la sede metropolitana de la iglesia ortodoxa rumana.

Dominan la ciudad los grandes edificios de la banca nacional, del teatro, de los Almacenes Victoria, etc. Hacia la periferia se abren grandes avenidas flanqueadas de tilos y rosales, que confluyen en el emblemático Arco de Triunfo. Fue llamada en su tiempo la ciudad "el pequeño París", no tanto por su trazado urbanístico o su modesto río Dânbovitza (sin parangón posible con el Sena), cuanto por su carácter abierto y cosmopolita. La época comunista, por su parte, precisaba erigir sus monumentos exaltando sus héroes y mártires. A la par ha ensanchado la ciudad construyendo polígonos grisáceos de viviendas uniformes, de aspecto carcelario, colmenas destinadas a la clase obrera. A partir de los años 80 , en plena dictadura de 
Ceauşescu, la ciudad se transforma nuevamente. El conducátor, presa de una fiebre de hybris constructora, decide edificar su propia urbe, monumento a la vez que mausoleo con el que perpetuar su nombre y fama. Su afán desmesurado por convertirse en el "supremo arquitecto" lo asemeja a Caín, que desafía a la divinidad, mata a su hermano Abel y construye la primera ciudad hostil a los ojos de Dios. Así, el constructor comunista emprende una frenética actividad demoledora de viviendas y templos. Calles enteras desaparecen y la urbe se convierte en un solar en construcción, un mar de escombros en el que varias generaciones entierran su pasado y sus vivencias. Se pretende con ello ilusamente sistematizar el espacio urbano a la manera de un nuevo Haussmann, abriendo nuevas y amplias avenidas; pero ante todo, la culminación de la obra malévola, como es la construcción de la llamada "Casa del pueblo". El dictador concibe su hogar como un búnker, a la par que un templo y monumento al poder, erigido al precio de inmolar a un pueblo entero.

Ceauşescu reproduce en este caso un mito de construcción inserto en el acervo cultural de filiación balcánica: el del Maestro Manole, el constructor que en vano intenta levantar un templo sin igual, admiración del mundo, toda vez que lo alzado por el día se desmorona de noche. Ante esa situación desesperante, un sueño premonitorio le da la solución. Para que su obra permanezca en pie, habrá de inmolar al primer ser viviente que por allí aparezca; éste resulta ser su propia esposa, embarazada del hijo de ambos. El monasterio al fin llega a construirse merced al sacrificio de sus seres queridos. También el "arquitecto" comunista construye al precio del sacrificio humano, mas no de sus seres queridos (si los tiene), sino de todo un pueblo al que condena en aras de su autoelevación, pues su obra megalómana ha costado sangre, sudor, miseria y vidas múltiples.

La caída del régimen comunista -en diciembre del año 1989con la muerte del dictador deja sin terminar el edificio. El templo del poder se convierte en un profano centro multiuso que alberga instituciones heteróclitas, desde la sede del Parlamento rumano hasta institutos de investigación. El visitante, por un módico precio, puede disfrutar de un espacio creado por un demonio cruel, un edificio que, en parte descuidado por su ruinoso mantenimiento, da fe de la tragedia colectiva. Casa poporului representa el símbolo de la ignominia como cementerio de toda una generación, profanado por el juego político y los distintos empleos que actualmente se le asignan.

La literatura rumana postmoderna viene obviando el citado monumento como materia para su escritura, tal vez con la intención de sumergirlo en el mar del olvido y despojarlo de su aureola mítica. Ello no obstante, Mircea Cartarescu, uno de los más relevantes narradores en lengua rumana, aborda el asunto en el último tomo de su novela Orbitor, cuyo comienzo temporal data de ese fatídico 
septiembre del año 89. Dicho autor describe en un par de ocasiones Casa poporului como un monumento que genera el nacimiento de una esperanza, encarnada en la venida al mundo de un nuevo ser, al tiempo que es el ara inmoladora de toda una ciudad. Cartarescu imagina en su novela cómo las esculturas de la urbe, de los tiempos presentes y pasados: ninfas, faunos, putti y otras figuras mitológicas, así como hombres de estado y próceres de la cultura -unos posados como simples bustos, otros alzados sobre planta ecuestre-, cómo esas esculturas -repetimos- se levantan en la noche mágica que plasma en la novela referida, cobran vida y deciden acudir, guiados por un comandante de la Securitate rumana y por su mujer, gran activista del partido comunista, a la Casa poporului. Con ello el novelista procede a describir, punto por punto, los elementos artísticos que pueblan las estancias y los corredores del edificio, todo ello admirado por aquellas estatuas semovientes. Allí encuentran al ente superior destinado a dar vida al niño de la esperanza. Este momento cobra un evidente valor simbólico en que se contraponen el año de la muerte del dictador, cercano a concluir, y el próximo nuevo año en el que se realice la esperanza de una nueva vida, derribados los muros de una dictadura que ha llevado a la ruina a la ciudad y a la nación entera. No obstante, las figuras del pasado rechazan ese cambio inminente.

Casa poporului es un lugar de encuentro heterogéneo, que como tal pierde su carga ominosa para hacerse regazo de esperanza. Pero por desgracia la literatura no va más allá del ensueño deslumbrante y del deseo ardiente, pues al fin y a la postre se impone la prosaica realidad y, querámoslo o no, esa "Casa del pueblo" es lo que es: un vulgar edificio como cualquier otro; pero eso sí, monstruosamente enorme, donde se agolpan todo tipo de centros y de agencias faltos de lugar propio en Bucarest. Puede vérselo pues como un arrumbadero del comunismo derrotado, de la elefantiasis arquitectónica de un dictador demente y megalómano, a la vez que dejando a un lado sus connotaciones negativas- un lugar de trabajo para una multitud de ciudadanos que acuden cada día en pos de su sustento, por entero insensibles y olvidados de lo que el edificio signifique en muertes y desgracias anteriores.

A modo de ilustración a este respecto, veamos dos pasajes de la novela en cuestión de Cartarescu, extraídos del tercer tomo, titulado "Orbitor aripa dreapta":

Delante, inmenso como un trasatlántico varado en dique seco, se eleva sobre su ola de tierra la Casa del pueblo, cuya magnitud no alcanzable a un golpe de vista, ni aún para los ojos enormes de las pétreas estatuas, cortan la respiración. Era Malpetruis, la ciudad Dite, fundada para acoger a los demonios y dioses paganos, para los titanes y "refains". Sus escalones de cedro superaban la estatura de 
un hombre; sus columnas cinceladas eran como basílicas de gruesas; cada una de sus torres abarcaría toda una ciudad, rasgaban las nubes y herían la piel del mundo, blanda como de yema. Sin cruzar palabra, todos se dirigían hacia la construcción más colosal y triste del orbe. (Cartarescu 1997: 475)

Casa poporului no era de hecho como ningún otro edificio del mundo presente ni de tiempo alguno. En el ingente cuerpo de mamut de la quimera "ceausista", podías reconocer la Universidad Lomonosov, el faro de Alejandría, el Empire State Building, los zigurats y las pirámides, el Reichstad, la torre de Babel y hasta las construcciones ciclópeas de las islas Canarias, vestigios de una Atlántida desaparecida, o los inmensos cilindros graníticos de la Tiahuanaco, o las construcciones de Cydonia, Cara Fortaleza y Pirámide, pues cuanto había alzado en todo tiempo el orgullo humano o de los ángeles, caducidad de conchas que duran un momento, albergando el cerebro tibio de la humanidad, ahora están convertidas en añicos unos ocho millares de esas conchas en la orilla del gran océano, representado por esa inmensa mole, poblada de ventanas del desierto central de una ciudad en ruinas. Las montañas han sido despojadas de sus mármoles; los ríos, de sus arenas; las venas minerales de oro y hierro, agotadas hasta el último grano de su mena. Miles y miles de esclavos habían trabajado durante largos años en la desmesurada construcción del nuevo faraón, mezclando el material con huesos y sangre humana, hasta enterrar incluso su propia sombra bajo los cimientos del monstruoso monasterio. (Cartarescu 1997: 477)

Todo ello nos indica que este sitio, ya en la realidad o en la literatura en que ha sido plasmado, conforma un lugar mítico de nuestra Europa que, junto con el muro de Berlín, o con los campos de concentración, como el de Auschwitz, significan lo que dice Roland Barthes: "Mito es historia"; así, quienes la cuentan hacen que el mito perdure a través de la literatura o a través de otras formas de escritura.

\section{El espacio cerrado del gueto Rocío PeÑalta CATALÁN}

Si hemos elegido el gueto como uno de los espacios míticos o, mejor, mitificados de la ciudad, no es sólo por sus características físicas -un espacio cerrado, cárcel para quienes viven dentro, lugar misterioso y prohibido para quienes viven fuera de él-, sino también por la productividad que ha tenido este espacio en la literatura y el cine, desde la comedia de William Shakespeare El mercader de Venecia (1596-1597) hasta su adaptación cinematográfica (Radford, dir., 2004), desde la novela El Golem de Gustav Meyrink (1915), ambientada en el gueto de Praga hasta la película La lista de 
Schlinder (Spielberg, dir., 1993), que refleja la situación del gueto de Cracovia. Son muchos los ejemplos. Y esto sólo en lo que se refiere a la acepción clásica del término gueto, un concepto que, como veremos después, se ha lexicalizado, abarcando realidades diferentes y actuales. Vamos a empezar con una definición del gueto y con sus orígenes históricos para pasar después a lo que hoy se puede entender como "gueto".

Según el Diccionario de la Real Academia Española, el término "gueto", en su primera acepción, tiene el significado de "judería marginada dentro de una ciudad". La palabra procede del italiano 'ghetto' y esta, a su vez, del dialecto véneto: 'geto', lugar donde se funde metal para fabricar cañones (Brewer 2006: 65).

ghetto A. s. m. 1 Rione dove, in alcune città, erano costretti ad abitare gli Ebrei [...] | (est.) Quartiere cittadino, squallido e povero, in cui si raggruppano, più o meno coattivamente, le minoranze, socialmente escluse, di una comunità $[\ldots]$.

$\square$ ghétto [dal n. dell'isoletta venez., dove, nel Cinquecento, vennero relegati gli Ebrei, così chiamata perché ivi era una fonderia (dial. ghèto 'getto') 1516]. (Zingarelli 2010: § ghetto)

GHETO, (coll'e larga) a. ro. Ghetto, Parola che il Muratori fa derivare dalla voce Rabbino - Talmudica Qhet, che vale Separazione, divorzio: benché altri creda che provenga dalla Siriaca lighello che vuol dire Congregazione, Sinagoga; chiamasi il Serraglio dove abitano gli Ebrei. (Boerio 1867: § gheto)

GETO, a. m. Getto e Gitto, Impronta che si fa nella forma per fondervi metalli. (Boerio 1867: § geto)

Efectivamente, el primer gueto de la historia fue el Ghetto Novo de Venecia, creado en 1516 para albergar a los judíos residentes en la ciudad, en su mayoría de origen alemán, y ubicado en un lugar donde había existido una fundición, como comentaré más adelante. Aunque la actividad de los prestamistas judíos había sido autorizada por el gobierno de Venecia, durante todo el Quattrocento los hebreos tenían prohibido permanecer en la ciudad durante más de quince días seguidos, y debían espaciar cuatro meses sus visitas. Además, sólo se les permitía trabajar en determinados bancos y debían llevar una insignia 0 un sombrero amarillo identificativos. Sin embargo, mediante diversos subterfugios, los hebreos lograban evitar estas restricciones, y hay pruebas de que muchos tenían domicilio en la ciudad de los canales pese a la prohibición expresa de hacerlo. A principios del siglo XVI, a pesar de su aparente esplendor, la República de Venecia estaba en crisis: envuelta en varias guerras, presionada por lo patricios que necesitaban dinero para continuar con sus actividades económicas, empobrecida por un repentino aumento 
de la población, etc. El Senado veneciano valora entonces la posibilidad de renovar los acuerdos firmados con los judíos, cuyo "cuartel general" se encontraba entonces en Mestre, y que con su actividad de prestamistas podían facilitar la circulación de dinero en efectivo que necesitaba la República en ese momento.

Se decide permitirles continuar con el ejercicio del préstamo, tanto contra empeño como con garantía escrita. Según el acuerdo de 1508 , podían aceptar cualquier tipo de empeño salvo armaduras y objetos sagrados, como cruces, cálices, paramentos, misales, etc. Se les eximía de cualquier responsabilidad en caso de incidente, hurto, incendio o saqueo. La duración máxima del préstamo podía ser de quince meses. Podían alquilar las casas en la ciudad, pero sin derecho a adquirirlas en propiedad. Se les permitía tener un cementerio propio (en el Lido), una sinagoga y un albergue para recibir "hebreos extranjeros". Desde el Jueves Santo hasta el domingo de Pascua debían permanecer encerrados en casa, tanto por respeto a los cristianos como por su propia seguridad. A cambio, las autoridades locales les protegían y garantizaban su seguridad (Calimani 2001: 4041).

Pero en los años siguientes, a raíz de las epidemias de peste, las prédicas de frailes y sacerdotes fanáticos, y las protestas populares contra los judíos, se empieza a considerar necesario su confinamiento en un espacio cerrado, pues hasta entonces los hebreos habían vivido repartidos en diferentes zonas de la ciudad. La primera propuesta llegó al Consiglio dei Pregadi en marzo de 1515, de parte de un patricio, Emo Zorzi, que sugería que los hebreos de Venecia fuesen recluidos en la isla de la Giudecca ${ }^{1}$. Los líderes judíos se opusieron a esta elección y propusieron una alternativa: Murano.

Un año después, el 20 de marzo de 1516, Zaccaria Dolfin atacó duramente a los hebreos, acusándoles de muchas iniquidades, de construir ilegalmente sinagogas y de corromper al Estado, y pidió que fuesen confinados en el Ghetto Novo, espacio similar a una fortaleza, donde había existido una fundición, ya en desuso, en la parroquia de San Girolamo. El dux y los patricios dieron su aprobación, pensando que de esta manera se restringían las libertades de los judíos y sería más fácil controlar sus actividades. El 29 de marzo de 1516 se dictó un decreto según el cual los judíos tenían la obligación de residir en el ghetto:

\footnotetext{
${ }^{1}$ Se ha especulado a menudo sobre el origen del nombre de Giudecca -al principio, la isla era conocida como Spinalunga- relacionándolo con la presencia de judíos en ella. Sin embargo, hay diferentes versiones y esta hipótesis parece tener una base más legendaria que real (vid. Calimani 2001: 6).
} 
Li Giudei debbano tutti abitar unidi en la Corte de Case, che sono in Ghetto appresso San Girolamo; ed acciocché non vadino tutta la notte attorno: Sia preso che dalla banda del Ghetto Vecchio dov'è un Ponteselo piccolo, e similmente dall'altra banda del Ponte siano fatte due porte cioè una per cadauno di detti due luoghi, qual Porte se debbino aprir la mattina alla Marangona e la sera siano serrate a ore 24 per quattro Custodi Cristiani a ciò deputati e pagati da loro Giudei a quel prezzo che parerà conveniente al Collegio Nostro. (Calimani 2001: 43)

El recinto debía ser completado con dos altos muros: todas las salidas serían cerradas y las puertas y las ventanas tapiadas, salvo las dos entradas indicadas en el decreto. Los judíos debían pagar a los vigilantes cristianos que guardarían las puertas del gueto durante la noche, además de dos barcas que continuamente, día y noche, recorrerían los canales que circundaban la zona. Como se ve en la imagen, el gueto es una isla totalmente rodeada de canales, un espacio aislado.

A pesar de todas estas restricciones, los judíos habían conseguido su objetivo, perseguido desde el siglo XIV: un barrio propio en el que residir.

El debate contra los judíos nunca se llegó a calmar del todo. Periódicamente surgían protestas contra los hebreos, incitadas por predicadores exaltados que consideraban que todas las desgracias se debían a los judíos y que Dios había retirado su favor a las ciudades que acogían a estos infieles. Para tratar de contrarrestar el peso de los prestamistas judíos en la sociedad, la iglesia creó los Montes de Piedad, que tenían el objetivo de prestar dinero a los pobres sin cobrarles intereses. Sin embargo, la mala gestión de estas instituciones y lo limitado de sus funciones hacían que los bancos de los hebreos siguiesen resultando más útiles al Estado y a los patricios. Además, en 1541, debido a la llegada de los judíos españoles y portugueses expulsados de sus territorios en 1492 y 1496 respectivamente, el gueto tuvo que ampliarse, incluyendo también la calle del Ghetto Vecchio (Calimani 2001: 52; 2002: 9).

En el gueto de Venecia, a mediados del siglo XVII, llegaron a vivir casi cinco mil hebreos (Calimani 2001: 169). El hacinamiento de las familias judías se manifiesta en el número de plantas de los edificios de viviendas del gueto, que superan en altura a las del resto de la ciudad.

Aún hoy, sigue habiendo judíos en el gueto de Venecia, aunque evidentemente ya no es un lugar aislado. Las sinagogas siguen celebrando sus ceremonias, hay un colegio judío, tiendas de antigüedades y de artículos religiosos y restaurantes kosher, además de un museo hebraico. En las guías turísticas aparece como un lugar de interés para visitar. 
Como hemos visto, el origen del gueto como barrio donde se aísla a la población judía de una ciudad es muy antiguo, sin embargo, estos espacios cobrarán especial relieve con el auge de las ideologías totalitarias del primer tercio del siglo XX.

Si volvemos de nuevo a las definiciones del Diccionario de la Academia, vemos que hoy en día, el término "gueto" tiene un significado mucho más amplio:

gueto (Del it. ghetto).

1. m. Judería marginada dentro de una ciudad.

2. $m$. Barrio o suburbio en que viven personas marginadas por el resto de la sociedad.

3. m. Situación o condición marginal en que vive un pueblo, una clase social o un grupo de personas.

Hoy se denomina "gueto" a cualquier barrio dentro de la ciudad en el que viven personas marginadas 0 a zonas con alta concentración de población extranjera. El uso de esta expresión se ha generalizado y es muy frecuente encontrarla en los medios de comunicación. Cabría preguntarse entonces si el "gueto", en el sentido más amplio que tiene hoy esta palabra, sigue siendo un espacio mítico o, por el contrario, se ha desmitificado por completo.

\section{El estadio: un icono moderno}

Javier Rivero Grandoso y Karlos Cid AbASOlo

El estadio de fútbol es una de las construcciones modernas que prevalece en las ciudades de todo el mundo, no ya solo en Occidente. Cada localidad, por pequeña que sea, tiene un campo de fútbol, utilizado principalmente para la práctica de este deporte u otros que se puedan desarrollar en este espacio, como rugby o atletismo.

Sin embargo, estas construcciones son también usadas para otro tipo de eventos, como la celebración de conciertos, algo muy frecuente ya que es una fuente de ingresos nada desdeñable; la llegada de los Reyes Magos, como ocurre en el Heliodoro Rodríguez López, estadio en el que juega como local el Club Deportivo Tenerife (figura 1); e incluso el oficio de una misa, como sucedió en 1982 cuando el Papa Juan Pablo II celebró la eucaristía en el Camp Nou. 


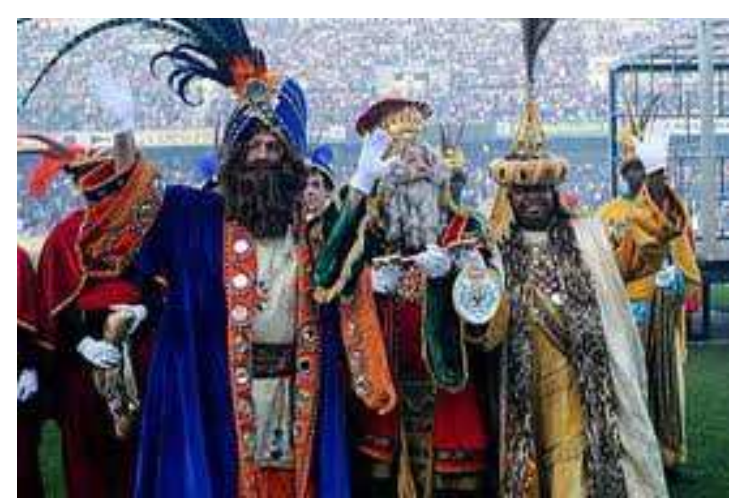

Figura 1. Reyes Magos en el Heliodoro Rodríguez López.

Tragedias como la ocurrida en Heysel en 1985 o la de principios de 2012 en Egipto, generan en estos estadios un aura mítica: los espacios reservados para el disfrute del aficionado se tiñen de sangre y muerte. Más escalofriante aún fue el caso del Estadio Nacional de Chile, que tras el Golpe de Estado de Pinochet fue utilizado como campo de concentración, donde se torturaba y asesinaba a militantes de partidos políticos de izquierda.

Vamos a centrarnos en un aspecto que ha sido discutido y tratado por intelectuales, como Manuel Vázquez Montalbán. En su obra póstuma Fútbol. Una religión en busca de un dios, un libro de ensayo hecho a partir de artículos publicados en la prensa, sostiene que el fútbol es la religión moderna, pero que todavía no ha encontrado a su dios.

Es previsible que en el próximo siglo uno de los mercados más activos sea el de las religiones, y frente a las religiones tradicionales, obsoletas, plastas, ya se alzan sectas de muy diversos tipos que proponen espiritualidades prêt-à-porter, y entre esas religiones laicas en Europa el fútbol tiene un porvenir inmenso, dotado como está de catedrales, feligresía y tramas mediáticas y comerciales dispuestas a que el apostolado futbolístico prospere. (Vázquez Montalbán 2005: 112)

El autor catalán señala los casos frustrados de Maradona, por su adicción a la cocaína y sus constantes polémicas, y el de Ronaldo, al que las lesiones lastraron e impidieron ser el número uno del fútbol mundial. Resalta Vázquez Montalbán los intereses comerciales de la FIFA y de las grandes compañías en consagrar a estos jugadores para poder rentabilizar los acuerdos publicitarios, y hace especial hincapié en la búsqueda de nuevos mercados, como lo fue la motivación que impulsó la celebración del Mundial de fútbol de 1994 en Estados Unidos.

Tal vez deberíamos corregir a Manuel Vázquez Montalbán y considerar al fútbol como una religión politeísta ya que promueve la creación desmedida de dioses y héroes fugaces, y la mayoría de ellos 
vuelve a caer pronto en el olvido. La carrera de un futbolista, que no suele sobrepasar los 15 años de competición al primer nivel, es aprovechada por las principales multinacionales para vender sus productos. Estas compañías son las que en buena medida ayudan a construir este mito efímero y que varía tan pronto como surja otro nuevo jugador que despierte el interés de los aficionados. Así, después del éxito de Ronaldo, surgieron otros jugadores como Rivaldo, Zidane, Beckham, Ronaldinho, Kaká, Messi o Cristiano Ronaldo, que han sido encumbrados para posteriormente, en mayor o menor medida, ser olvidados en detrimento de otros nuevos dioses.

El primer gran jugador divinizado fue Diego Armando Maradona, a raíz del Mundial de fútbol de 1986 celebrado en México. En el partido de cuartos de final que enfrentaba a Argentina contra Inglaterra, Maradona consiguió para su selección los dos goles, que todavía hoy son recordados por distinto motivo: el primero, por ser anotado con la mano; el segundo, por partir desde el mediocampo y evitar a seis rivales. Tras el partido, el jugador argentino se referiría al primer tanto como "la mano de Dios" para no admitir que había hecho trampa.

Con esos dos goles iniciaría una leyenda que se vería acrecentada con los títulos logrados con el Nápoles y la final del Mundial de 1990 disputado en Italia. Sin embargo, como todo mito, la carrera de Maradona se vio empañada por sus "muertes" y por sus "resurrecciones", debido a su adicción a la cocaína que mermó su carrera, ya que fue sancionado varias veces por el consumo de sustancias prohibidas. Los aficionados argentinos fundaron una nueva religión, no exenta de humor, para rendirle culto al futbolista: la Iglesia maradoniana.

En la actualidad, otros jugadores parecen disputarse ese lugar en el Olimpo futbolístico. El ejemplo más claro es Leo Messi, al que algunos se referían como "el Messias" o "D10S". El futbolista del Barcelona ha sido constantemente comparado con su compatriota Maradona, que llegó a ser su entrenador en la selección Argentina. Sus registros goleadores y la calidad de su juego lo han situado entre los mejores de la historia, con tantos muy similares a los de Maradona, ya que contra el Getafe en semifinales de la Copa del Rey en el año 2007 consiguió marcar tras eludir desde el centro del campo a varios rivales, y también anotó un gol con la mano contra el Espanyol ese mismo año.

Tras conseguir cinco goles en un solo partido contra el Bayer Leverkusen, en la competición de Champions League, en 2012, tres de los principales diarios deportivos españoles coincidieron en sus portadas, en las que se referían a sus cinco tantos como "la manita de Dios" (figura 2). 

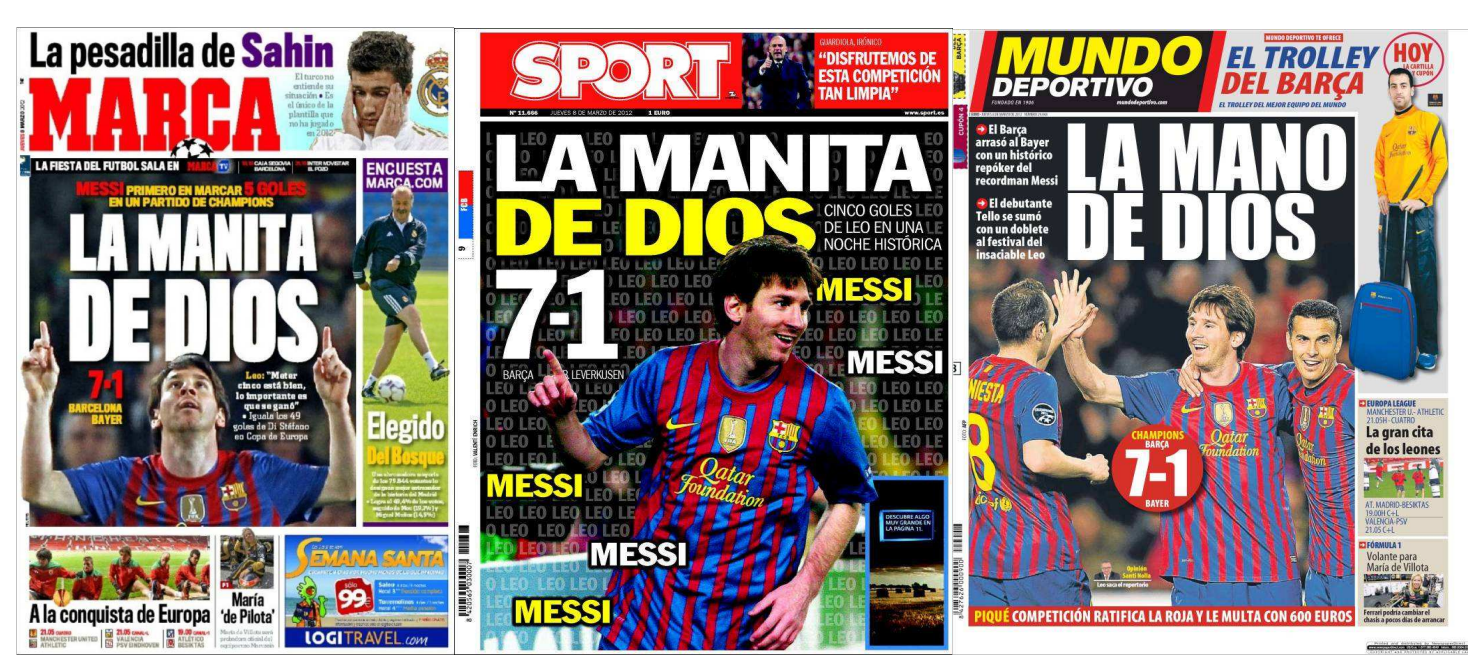

Figura 2. Portadas de tres diarios deportivos con los cinco goles de Messi.

La prensa es uno de los elementos que más influyen en la divinización de los deportistas, equipos o incluso sistemas de juego. La prestigiosa publicación francesa L'Équipe, por ejemplo, realizó un reportaje especial sobre el juego del Barcelona, en el que se renovaba la Santísima Trinidad: Johan Cruyff el padre, Josep Guardiola el hijo y Leo Messi el Espíritu Santo (figura 3). BARÇA

\section{L"Équipe' anuncia un especial sobre el Barça amb la Santíssima Trinitat: el pare (Cruyff), el fill (Guardiola) i l'Esperit Sant (Messi)}

La publicació francesa oferirà un especial aquest dissabte, 21 d'abril, amb entrevistes exclusives a Johan Cruyff, Sandro Rosell i Xavi Hernández

ARA Paris | Actualitzada el 16/04/2012 16:11

El diari francès 'L'Équipe' prepara un especial sobre el Barça per acompanyar l'edició d'aquest dissabte, 21 d'abril. El prestigiós rotatiu francès anuncia que publicarà entrevistes exclusives amb Johan Cruyff, Sandro Rosell i Xavi

Hernández.

El suplement tindrà un cost de dos euros is' ha anunciat amb el següent lema: "100\% Barça, més que un club".

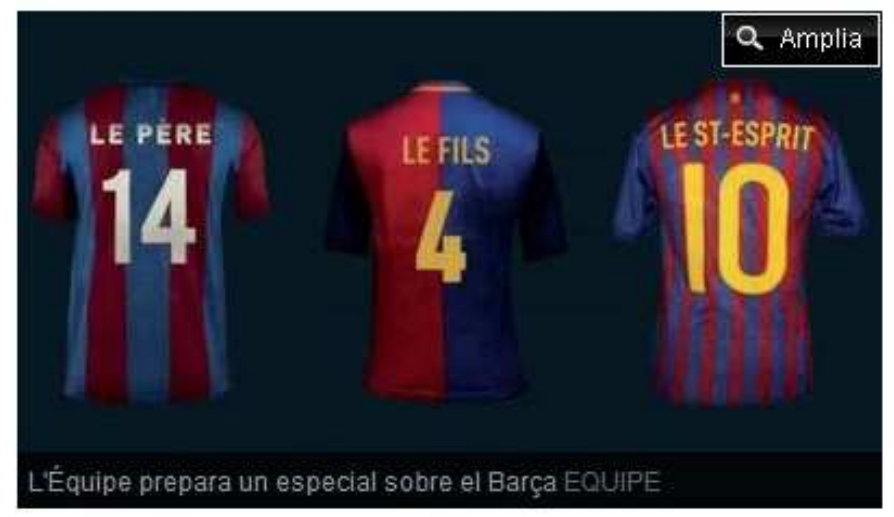

En la imatge de promoció, 'L'Équipe' mostra el dorsal de tres samarretes del Barça de diferents herois blaugranes i diferents èpoques de la història del club. Amb un 14 es refereix a Johan Cruyff, a qui considera "el Pare"; amb un 4, creu que "el Fill" és Josep Guardiola, i amb el 10 i una samarreta actual, diu

Figura 3. Artículo sobre la publicación del especial de L'Équipe. 
Los jugadores también son comparados con otras divinidades, como es el caso del portero Iker Casillas, considerado "el santo" por las paradas que realiza, que parecen imposibles y que en muchas ocasiones han salvado a su equipo de una derrota.

La línea editorial del medio de comunicación determina en gran medida la canonización de ciertos jugadores, lo que puede, cuanto menos, sorprender a los lectores. Fue lo que sucedió con el diario Marca, dirigido por aquel entonces por el criticado Eduardo Inda, cuando en 2010 la portada del periódico llevaba el titular "El tacón de Dios" para referirse a la asistencia, de tacón, que Guti hizo para que Benzema consiguiera un gol (figura 4).

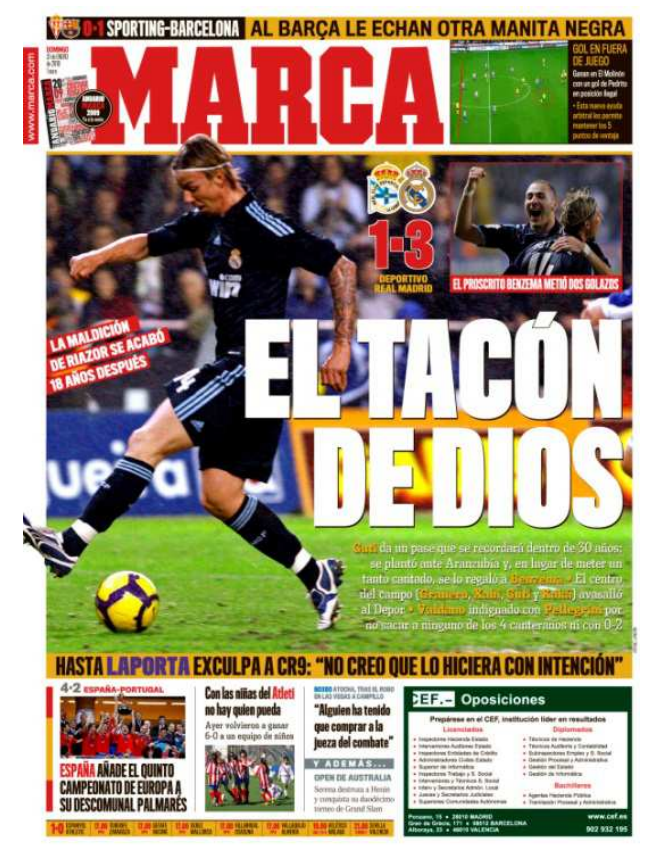

Figura 4. Portada del diario Marca.

Parece, entonces, que estamos ante distintos tipos de dioses diferenciados jerárquicamente, o, por lo menos, ante distintas religiones -algunas, como la de Maradona, con muchos fieles, y otras, como en este caso, minoritarias.

Si los jugadores son los héroes y dioses modernos, el estadio es irremediablemente el nuevo templo. Los fieles a esta religión acudirían escrupulosamente los domingos, como si asistieran a la misa, y actualmente, por el interés de las televisiones y de los organismos federativos en rentabilizar al máximo los derechos de explotación, cualquier día de la semana. Los aficionados entran al estadio a venerar y a aplaudir a estos nuevos dioses. Los hinchas alcanzan el éxtasis con los triunfos de su equipo, como se puede ver en la escena de la persecución, muy lograda, de El secreto de sus ojos (Campanella, dir., 2009). 
En esa secuencia, los agentes descubren que el asesino es aficionado al fútbol, y más concretamente al Racing de Avellaneda. Por ello, acuden al partido contra el Huracán para intentar encontrarlo. La cámara aérea se acerca al estadio, mientras la banda sonora y la narración de un comentarista futbolístico sumergen al espectador en la atmósfera de este tipo de eventos. La cámara, sin detenerse, muestra una jugada del partido hasta llegar a una de las gradas del fondo, detrás de la portería, en donde los aficionados, de pie, cantan y animan a su equipo. Entre la multitud, Benjamín -el protagonista, encarnado por Ricardo Darín- y su compañero buscan en vano al culpable, hasta que, casi por casualidad y cuando ya desfallecían, lo encuentran. Justo en el momento en el que van a detenerlo, Racing consigue marcar un gol, por lo que la grada estalla de júbilo y los aficionados alcanzan el éxtasis. El asesino aprovecha para escapar, mientras la cámara, como si fuera otro personaje, es zarandeada, lo que transmite el descontrol producido tras el gol del equipo. La persecución continúa por los pasillos y escaleras del estadio, en un magnífico travelling, hasta que el asesino, rodeado por los policías, se lanza al interior del campo, donde llega incluso a tropezar con un jugador, y es por fin detenido.

También en Salir pitando, película española dirigida por Álvaro Fernández Armero (2007), aparece el estadio en ebullición. Los protagonistas son el árbitro y los jueces de línea, encargados de pitar un trascendente partido en la última jornada de la Liga. Los aficionados abarrotan el templo moderno para ver ganar a su equipo.

En El delantero centro fue asesinado al atardecer, novela de la saga Pepe Carvalho de Manuel Vázquez Montalbán, de 1988, se exponen las ideas del autor acerca de la función de los futbolistas como dioses, y esa es la razón de las amenazas de muerte que recibe el flamante fichaje de un equipo que, aunque nunca se nombra, es claramente el Fútbol Club Barcelona. El estadio es, claramente, el templo.

Porque habéis usurpado la función de los dioses que en otro tiempo guiaron la conducta de los hombres, sin aportar consuelos sobrenaturales, sino simplemente la terapia del grito más irracional: el delantero centro será asesinado al atardecer.

Porque vuestro delantero centro es el instrumento que utilizáis para sentiros dioses gestores de victorias y derrotas, desde la cómoda poltrona de césares menores: el delantero centro será asesinado al atardecer. (Vázquez Montalbán 1988: 12-13)

En la actualidad, los estadios están recogiendo funciones propias de los templos religiosos. La necesidad de buscar cualquier fuente de ingresos ha obligado a los clubes a ser imaginativos $y$ ofrecer servicios hasta ahora insospechados. Así, en el Camp Nou ha 
comenzado la celebración de bodas, con recepción en el césped, aperitivo en los palcos y convite en la zona de tribunas (figura 5).

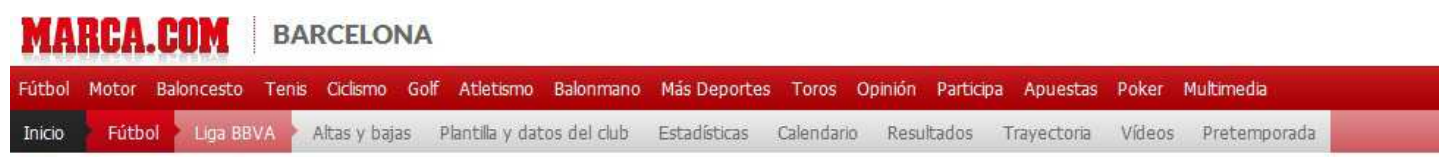

\begin{tabular}{|c|c|c|}
\hline WhMe gusta & $\begin{array}{l}\text { - A } 122 \text { les gusta una página, Registrate } \\
\text { para ver qué les gusta a tus amigos. }\end{array}$ & - Twittear 30 \\
\hline
\end{tabular}

\section{Primera boda en el Camp Nou}

- "Queríamos algo especial y no hay mejor sitio que éste", declaró el novio, ex jugador de hockey del Barcelona

10/07/11-16:37.

La pareja compuesta por Ibán Anglada, ex jugador de hockey del Barcelona, y Sigrid Sans se convirtió en la primera que se casa en el Camp Nou ante 260 invitados.

"Queríamos algo especial y se nos ocurrió el sitio", declaró Sans, economista de profesión. Casarse en el estadio cuesta entre 1.800 y 2.400 euros, en función del número de invitados.

El precio del banquete es de 110 euros por personas, y el Camp Nou es capaz de albergar hasta 750 comensales para este tipo de eventos.

Otros extras, como contar en el acto con los trofeos que el Barça ganó

M
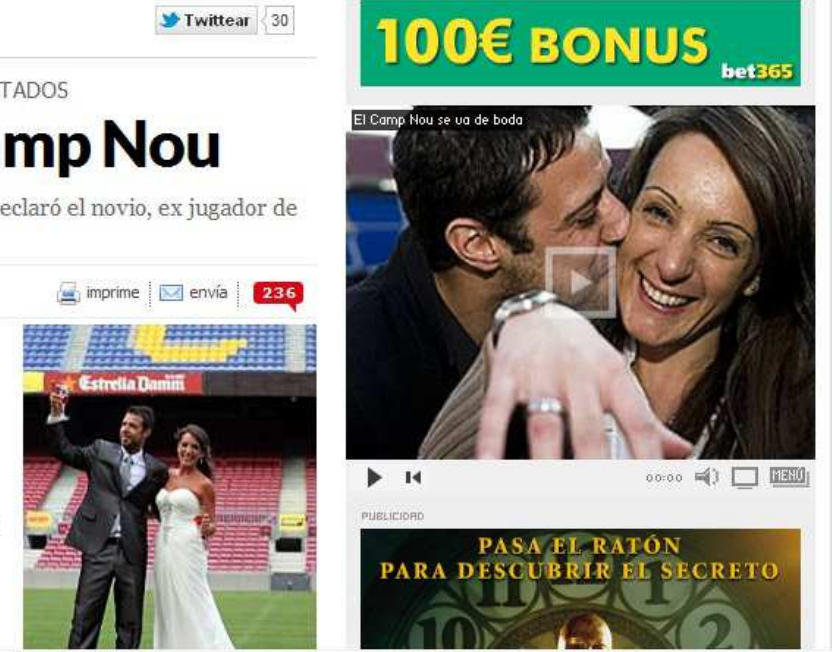

Figura 5. Noticia sobre la primera boda en el Camp Nou.

También ha aprovechado el club catalán, así como el Espanyol, el Atlético de Madrid, el Betis o el Hamburgo, una parte del estadio para depositar las cenizas de los socios y aficionados fallecidos que quieran descansar en estos templos futbolísticos. Con estos proyectos, los clubes se aseguran unos beneficios nada despreciables.

Con este fin, el Schalke 04 alemán ha creado un cementerio cerca de su estadio para que sus seguidores puedan ser enterrados junto al club de sus amores. Todavía no han trascendido los precios de este camposanto que se inaugurará en noviembre de 2012 (figura $6)$. 


\section{¡El Schalke 04 inaugura un cementerio para sus hinchas!}

Con capacidad para 1904 seguidores, el club alemán estrena este campo santo con vistas al estadio y con forma de terreno de juego

\begin{tabular}{|c|c|}
\hline$\star$ * is th $*$ Votos $(1):$ Comentarios $(0)$ & $\Leftrightarrow: \square: A A A$ \\
\hline \multicolumn{2}{|l|}{ SPORT.es } \\
\hline $\begin{array}{l}\text { Curiosa iniciativa la del cuadro germano en } \\
\text { honor a sus aficionados más fieles. Este mes de } \\
\text { noviembre el club inaugurará un cementerio } \\
\text { construido para sus seguidores. Con vistas al } \\
\text { estadio de Gelsenkirchen, este campo santo } \\
\text { tendrá } 1904 \text { tumbas, coincidiendo así con el año } \\
\text { de fundación de la entidad deportiva. }\end{array}$ & 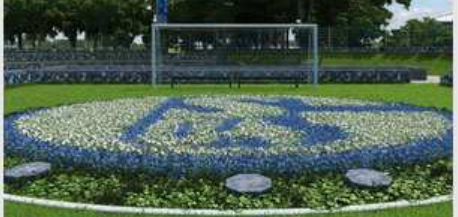 \\
\hline $\begin{array}{l}\text { Tras más de cinco meses de trabajo, un escudo } \\
\text { adornado con flores blancas y azules, los colores } \\
\text { del Schalke } 04 \text {, presidirá el centro de un }\end{array}$ & $\begin{array}{l}\text { - El escudo del Schalke preside este espacio } \\
\text { reservado para los aficionados más fieles | Foto: } \\
\text { schalke-fan-feld.de }\end{array}$ \\
\hline $\begin{array}{l}\text { espacio que trata de emular una cancha de } \\
\text { fútbol. }\end{array}$ & Ff Me gusta $20 \quad$ Tweet 8 \\
\hline $\begin{array}{l}\text { De esta manera, los aficionados del Schalke que } \\
\text { amen el fútbol podrán ser sepultados en este } \\
\text { peculiar recinto ideado por Ender Ulupinar, el }\end{array}$ & $16^{85}$ \\
\hline
\end{tabular}
creador de la obra.

"Varios famosos jugadores del equipo, así como
RSS Alemania 2
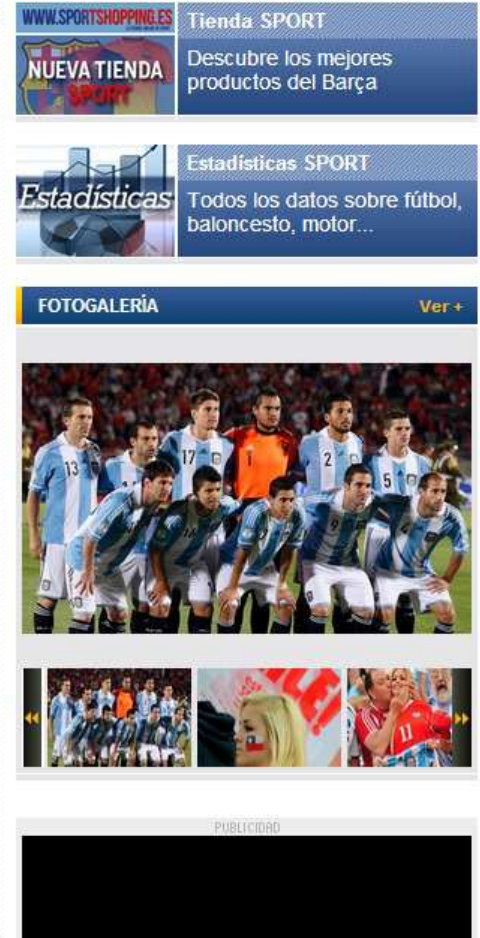

Figura 6. Noticia sobre el cementerio para los seguidores del equipo alemán.

Al aludir a la metáfora del estadio como templo, tenemos que referirnos obligatoriamente a San Mamés, estadio del Athletic Club de Bilbao, conocido como "La Catedral".

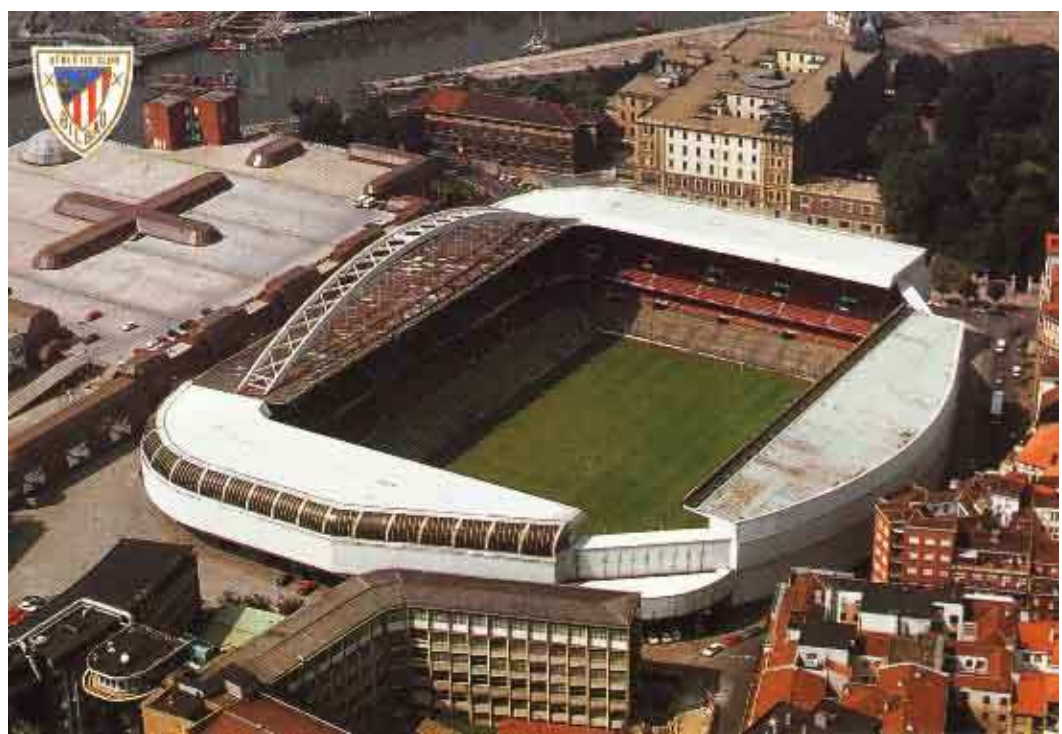

Figura 7. Estadio de San Mamés.

Este es el estadio de San Mamés, inaugurado el 21 de agosto de 1913, en el cual juega desde entonces (y por poco tiempo ya) el Athletic de Bilbao, el único equipo de la liga española que, junto al Real Madrid, nunca ha descendido a Segunda División. Hay que tener en cuenta que en la temporada 1933/1934, el F.C. Barcelona acabó 
noveno de los diez equipos que había en Primera, pero esquivó el descenso gracias a la reestructuración que se llevó a cabo, por la cual se amplió a doce el número de equipos. El Athletic tampoco ha jugado nunca ni siquiera la promoción de descenso a segunda (el F.C. Barcelona sí lo hizo, en la temporada 1941/1942).

En sus inicios había en el Athletic jugadores vascos e ingleses. Este hecho y la denominación inglesa del club hay que atribuírselos a que fueron los ingleses (en concreto, aquellos que a finales del siglo XIX trabajaban en la provincia debido a la industrialización de esta) los que introdujeron el balompié en la capital.

En esos comienzos, el Athletic utilizó una indumentaria similar a la del Blackburn Rovers. Sin embargo, a partir de 1910 se vio forzado a renunciar a ella, por lo que optó por una (la que ha llegado hasta nuestros días) que es imitación de la del Southampton F.C. Otra circunstancia que acentuó el carácter english del club fue que recurriera en numerosas ocasiones a entrenadores ingleses que, con sus métodos de trabajo, contribuyeron a la victoriosa trayectoria del equipo.

A los pocos años de su fundación, el Athletic renunció a seguir fichando jugadores ingleses. Desde entonces, mantiene fielmente la política de acoger solo a jugadores vascos, descendientes de vascos, jugadores no vascos pero educados futbolísticamente en su propia cantera, y jugadores de comunidades autónomas limítrofes.

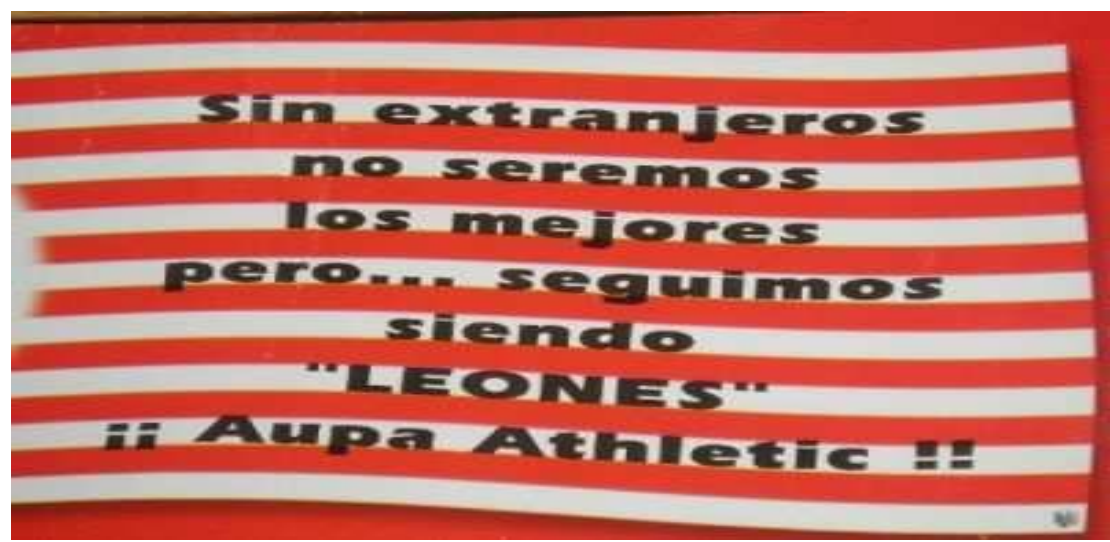

Figura 8. Orgullo rojiblanco por su política de fichajes.

Esta circunstancia ha sido aprovechada por ciertos medios de comunicación para contaminar el deporte con soflamas nacionalistas (figura 9). 


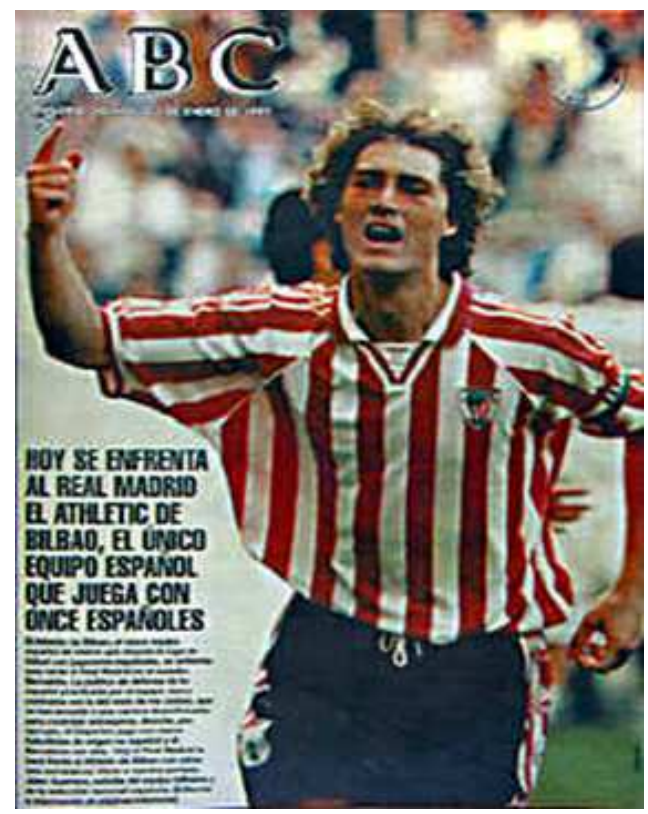

Figura 9. Portada del diario $A B C$.

En cualquier caso, y por las razones aludidas, el estadio de San Mamés es el único del mundo donde jugadores como Messi o Cristiano Ronaldo no podrían jugar en el equipo de casa, aunque lo pidieran de rodillas, aunque juraran tener un abuelo en la Rioja o en Cantabria, aunque estuvieran dispuestos a jugar gratis, por no llamarse Messigoikobitarte ni Cristianoetxea.

Eso sí: la fama de este equipo llega a todos los rincones del mundo (figura 10);

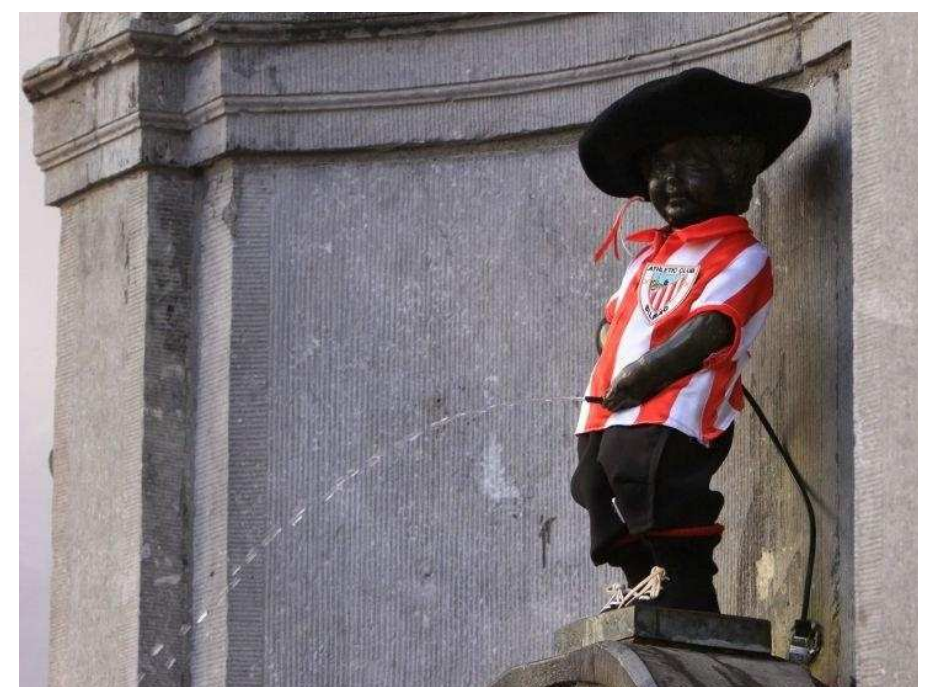

Figura 10. El Manneken Pis de Bruselas con la camiseta del Athletic.

y ha calado en numerosas especies de animales (figura 11). 

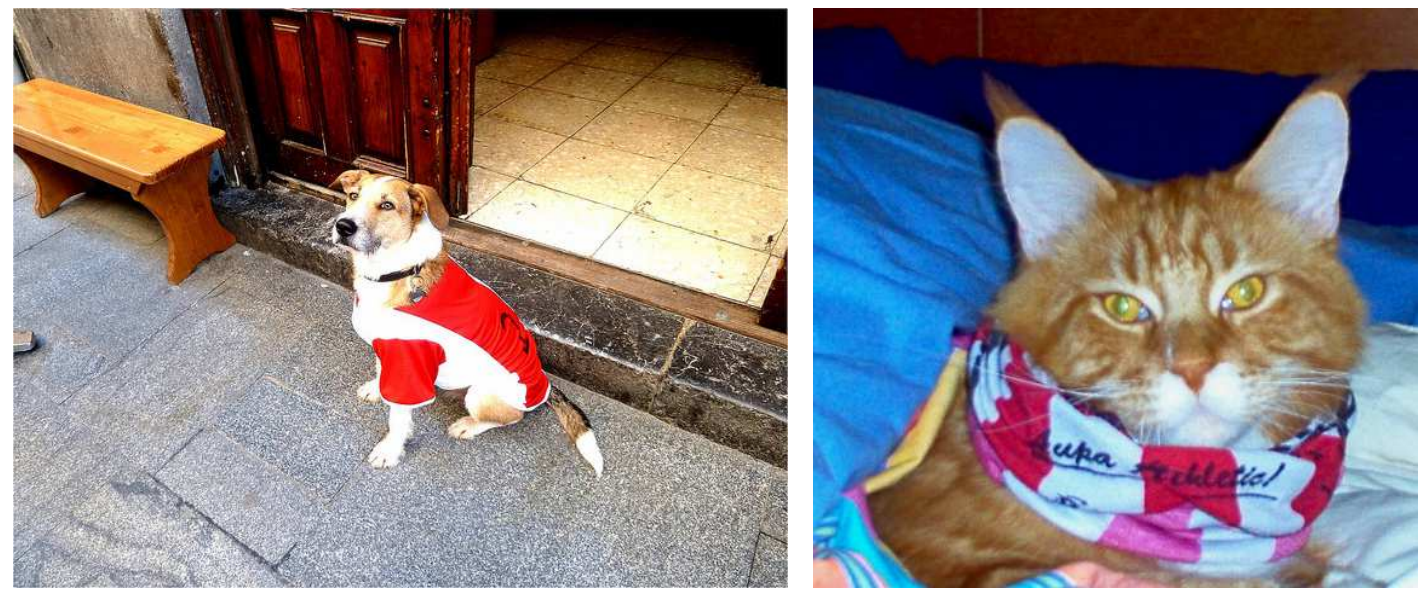

Figura 11. Mascotas seguidoras del Athletic.

Además, no entiende de siglas políticas (figura 12).

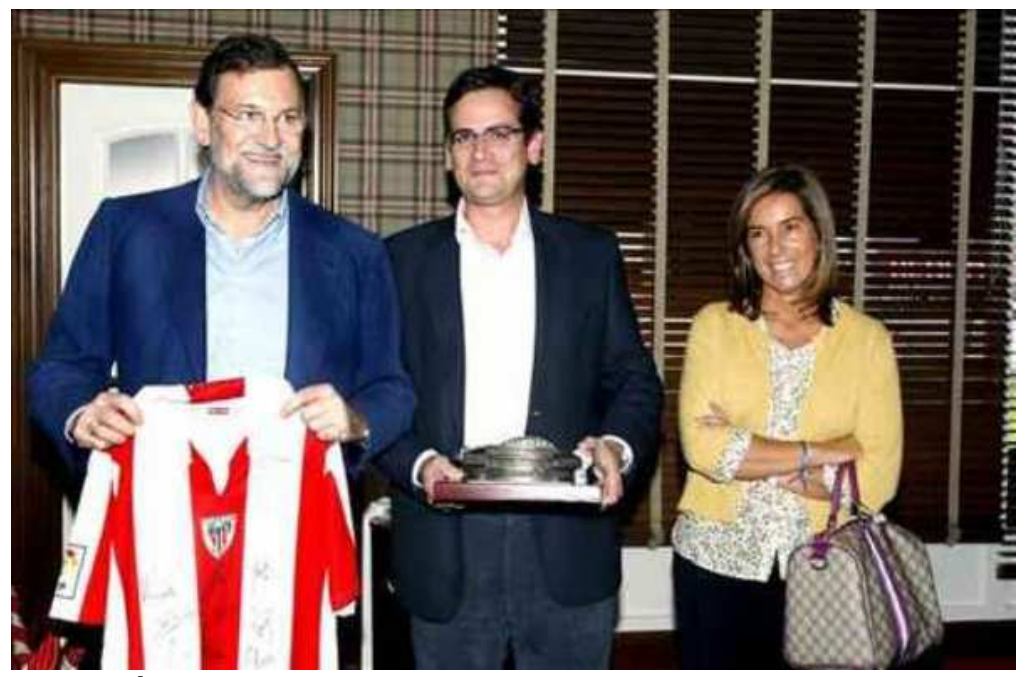

Figura 12. Políticos del Partido Popular con la camiseta del Athletic.

El primer jugador en marcar un gol en San Mamés fue Rafael Moreno "Pichichi" (figura 13). 

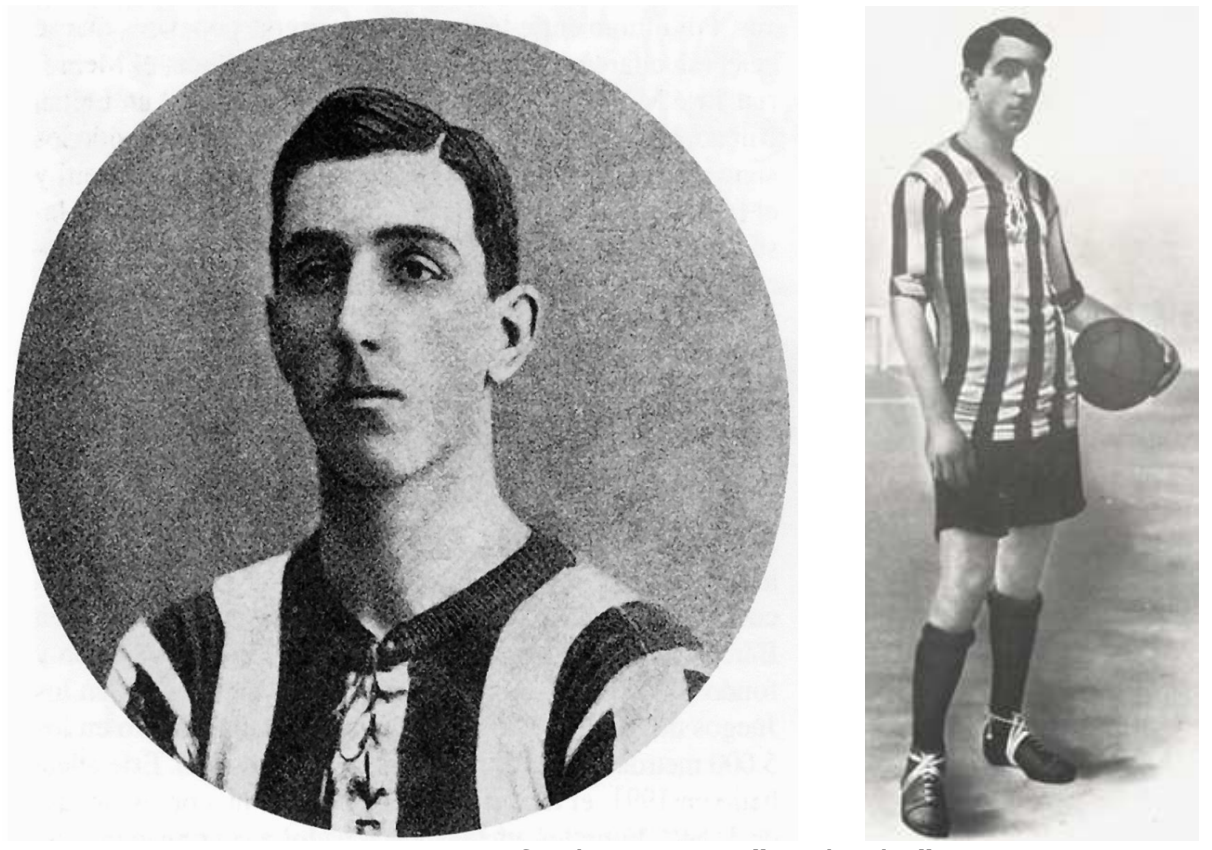

Figura 13. Rafael Moreno "Pichichi".

"Pichichi", sobrino de Miguel de Unamuno, fue un histórico jugador del Athletic que desarrolló su carrera entre 1911 y 1921, siempre en el conjunto rojiblanco. La gran cantidad de goles que metió durante esos años explica que dé su nombre al trofeo al máximo goleador de cada edición de la Primera División española.

Centrémonos ahora en el estadio. En sus orígenes, el Athletic jugaba en el campo de fútbol de Lamiako (en el término municipal de Lejona, limítrofe con Las Arenas, todo ello dentro del denominado "Gran Bilbao"). Cuando dicho estadio se quedó pequeño por el notable aumento en el número de aficionados, se vio la necesidad de construir uno de mayor capacidad. Surgió así, en 1913, el estadio de San Mamés, diseñado por el arquitecto Manuel María Smith.

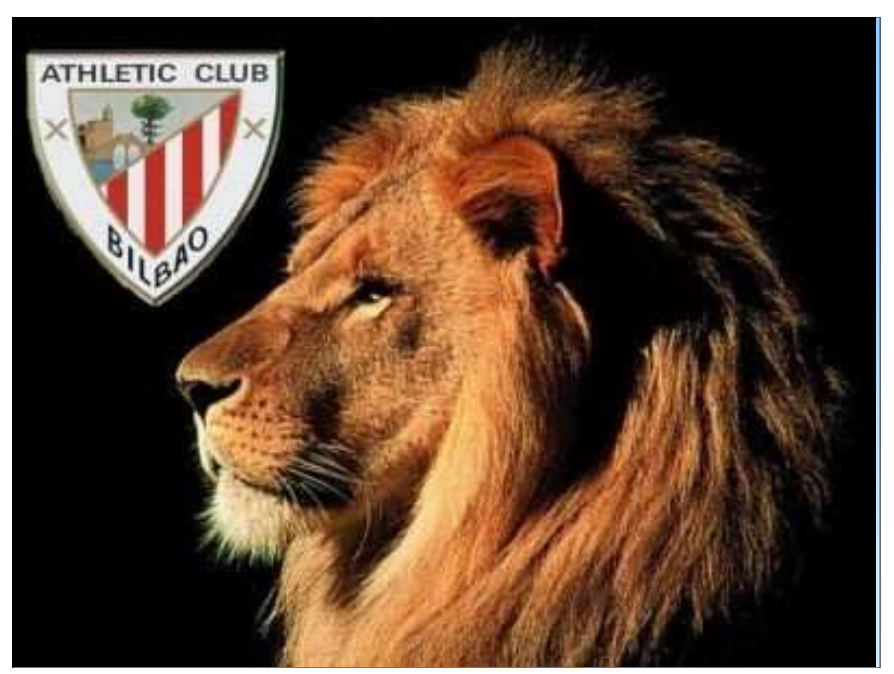

Figura 14. Los jugadores del Athletic reciben el apodo de "leones". 
El estadio fue llamado "San Mamés" porque fue edificado sobre unos terrenos que pertenecían a un asilo próximo que tenía dicho nombre. Los jugadores del Athletic reciben el apodo de "leones" (figura 14) debido a que, como todo el mundo sabe, San Mamés fue un mártir que, según algunas versiones, fue arrojado a los leones y devorado por estos (figura 15).

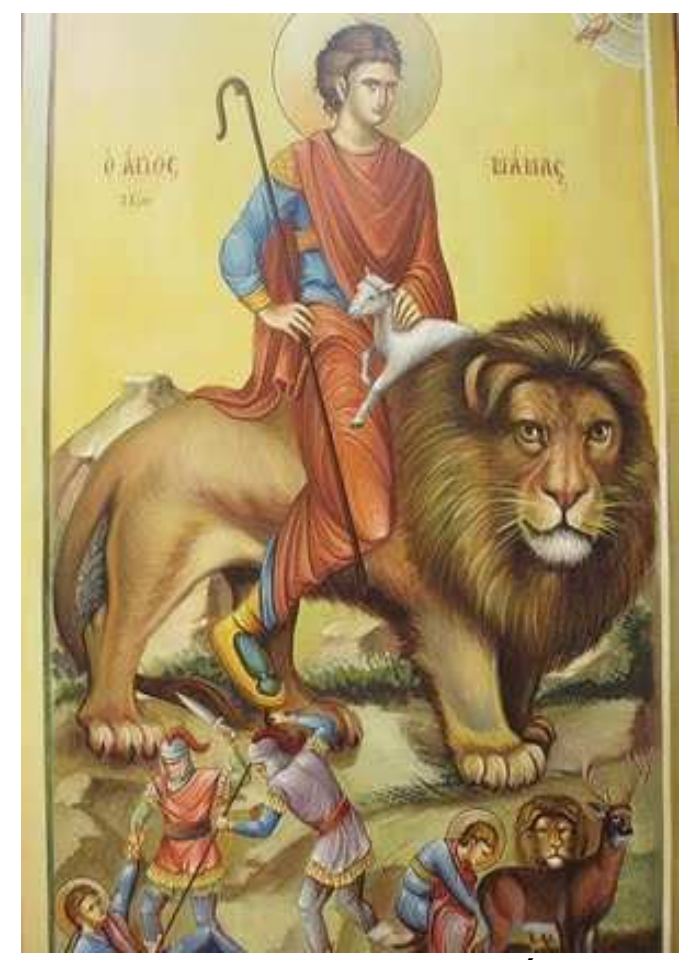

Figura 15. San Mamés.

A San Mamés, único estadio que ha albergado todas las ediciones de la Primera División española, se le conoce popularmente como La Catedral, en primera instancia por las connotaciones religiosas de su nombre oficial, si bien más adelante se empezó a usar como mera hipérbole futbolística (estadio como templo del deporte-rey).

Se prevé que el estadio llegue a ser centenario, puesto que su demolición, una verdadera tragedia para los nostálgicos, tendrá lugar en 2013, cuando se inaugure el nuevo San Mamés (San Mames barria en vasco, concretamente en dialecto vizcaíno), cuyas obras comenzaron en 2010 (figura 16). 

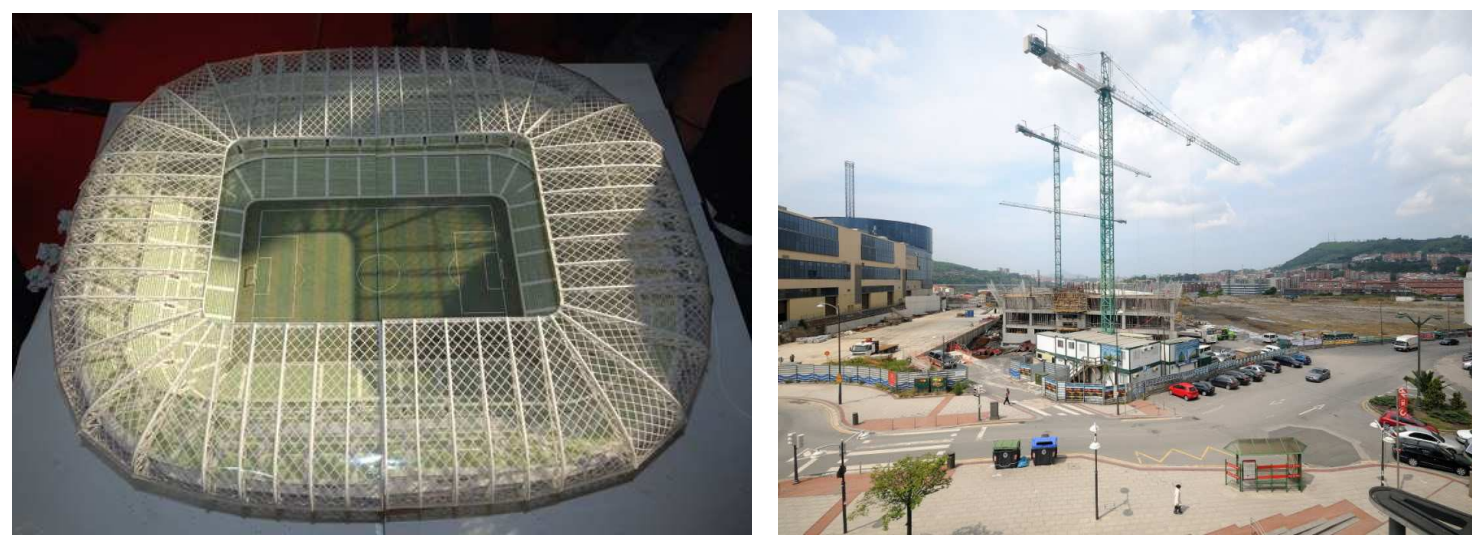

Figura 16. Proyecto y obras del nuevo estadio de San Mamés.

Entre 1952 y 1953 se remodeló la tribuna principal de San Mamés y fue incorporada una novedosa estructura metálica en forma de arco que, al evitar la existencia de columnas, permitía a los espectadores tener una mejor visibilidad del campo, sin barreras arquitectónicas. Dicho arco está en el centro de la polémica sobre la demolición de San Mamés y la edificación del San Mames barria: ante esta victoria de la modernidad sobre la tradición, se han organizado plataformas para que el famoso arco del estadio no sea destruido (figura 17).

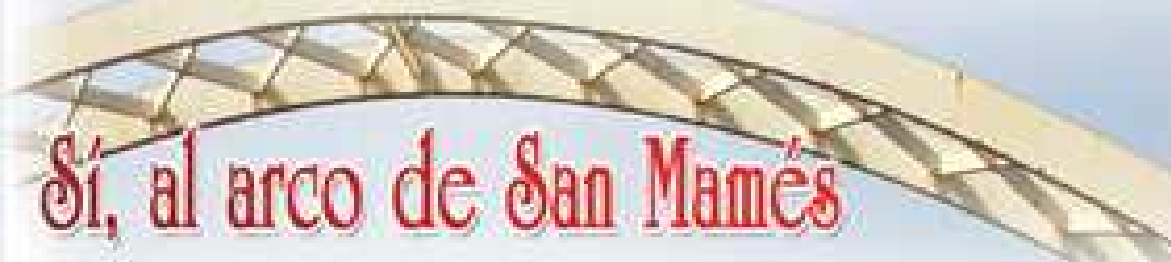

Figura 17. Cartel en pro de la conservación del arco de San Mamés.

El músico bilbaíno Kepa Junkera (figura 18) es el autor de la canción "Chulos hasta pa' perder", interpretada por Francis, vocalista del grupo Doctor Deseo. Esta canción resume en tres minutos el espíritu rojiblanco bilbaíno. 


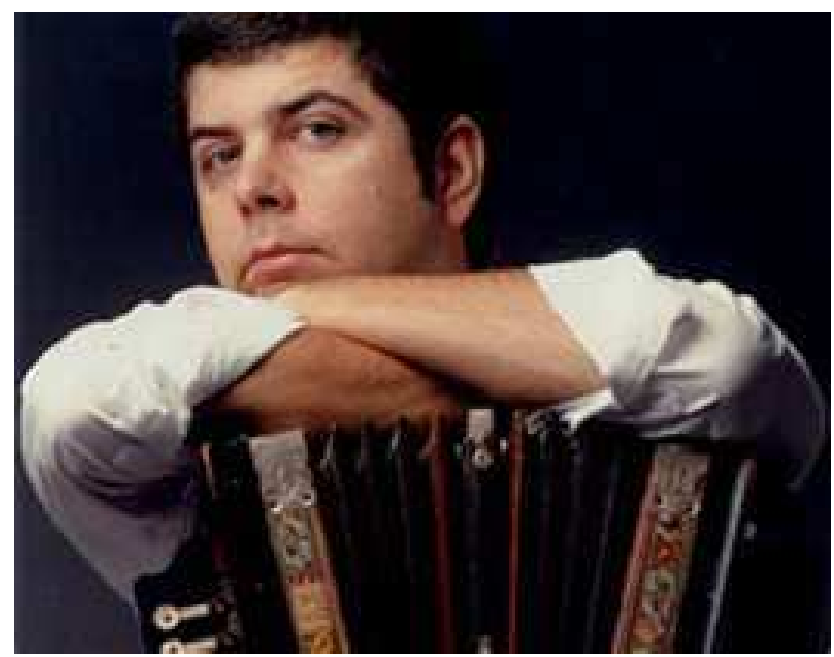

Figura 18. Kepa Junkera.

Escuchar canción: http://www.youtube.com/watch?v=abJLL-4zIgU

El equipo y su estadio han merecido la atención de numerosos estudiosos, tales como la antropóloga húngara Mariann Vaczi (figura 19).

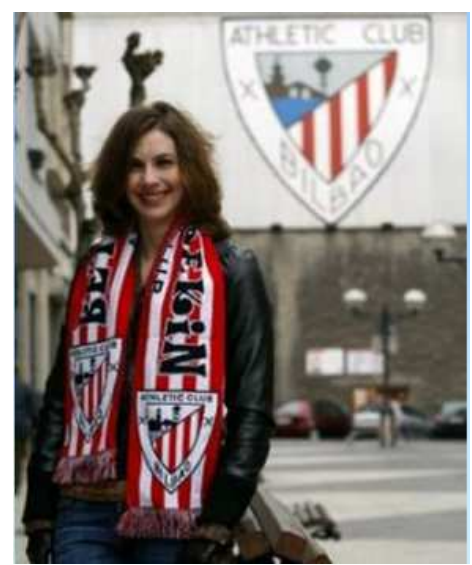

Figura 19. Mariann Vaczi.

Vaczi, tras licenciarse, preparó su tesis en el Centro de Estudios Vascos de la Universidad de Nevada, Reno (EEUU). A Vaczi le hablaron de "un equipo de fútbol que solo jugaba con jugadores de la tierra y que llevaba defendiendo esa filosofía más de cien años sin descender de categoría", y quedó impresionada. Propuesto el tema para la tesis en Reno, se lo aceptaron.

El estadio de San Mamés representa, entre otras muchas cosas, el orgullo colectivo frente a la inferioridad. La inferioridad estructural del equipo bilbaíno por su política de fichajes es asumida con orgullo por su afición, tal como podemos observar en este vídeo (fragmento de la película 300, con los diálogos manipulados), cuya predicción, lamentablemente, no se cumplió: 


\section{Ver vídeo:}

http://www.youtube.com/watch?v=BuqpWIGLOZs\&feature=related

San Mamés enamora, y como su política de fichajes no se hace extensible al fichaje de entrenadores, todos los entrenadores del mundo, por muy importante que sea el equipo al que están entrenando, se mueren por entrenar al club bilbaíno.

\section{Ver vídeo:}

http://www.youtube.com/watch?v=W2zES63EVRE\&feature=related

San Mamés no es solo un campo de fútbol. No es solo un símbolo del orgullo colectivo. Puede convertirse en espacios de muy diversos significados.

San Mamés es el templo donde lo milagros pueden ocurrir (figura 20).

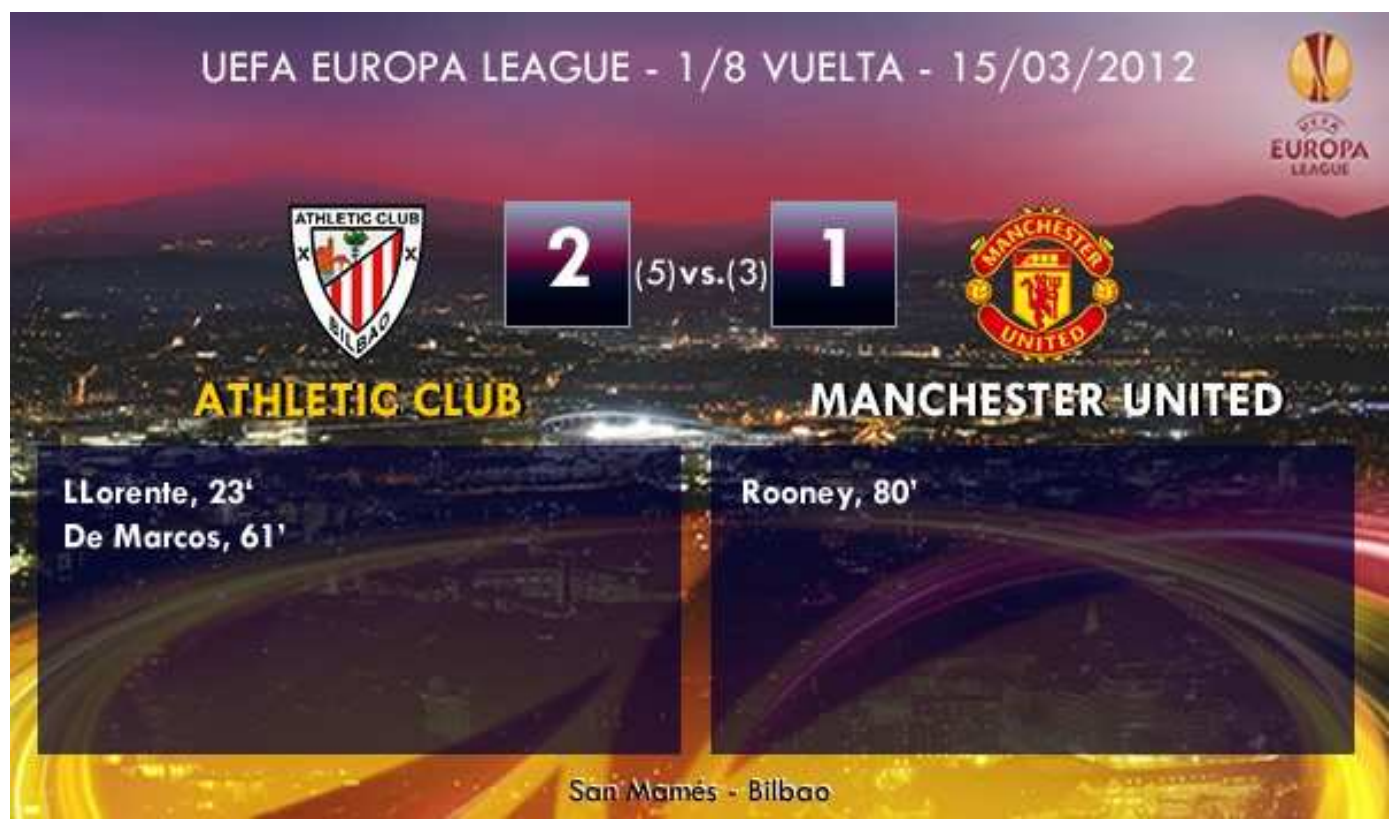

Figura 20. El Athletic vence al Manchester United.

Cuando un equipo juega por primera vez en San Mamés, es costumbre que su capitán deposite un ramo de flores ante la estatua de Pichichi (figura 21). El campo se hace espacio de homenaje y recuerdo. 


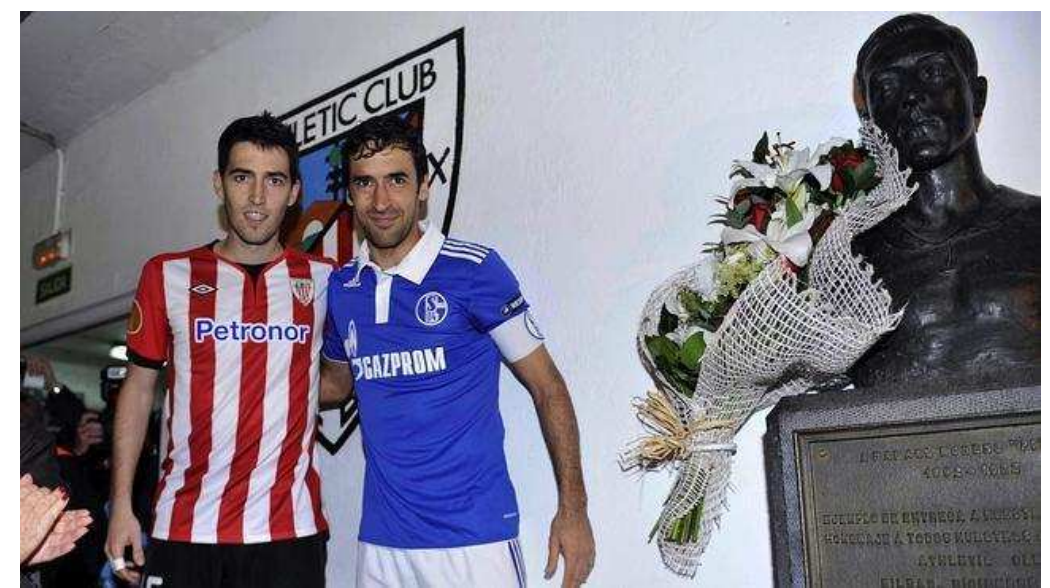

Figura 21. Raúl, acompañado de Iraola, rinde homenaje a Pichichi.

También el campo se convierte en espacio de homenaje y recuerdo cuando una pelota de goma lanzada por un miembro de la Policía Autónoma Vasca mata a un aficionado del Athletic (figura 22).

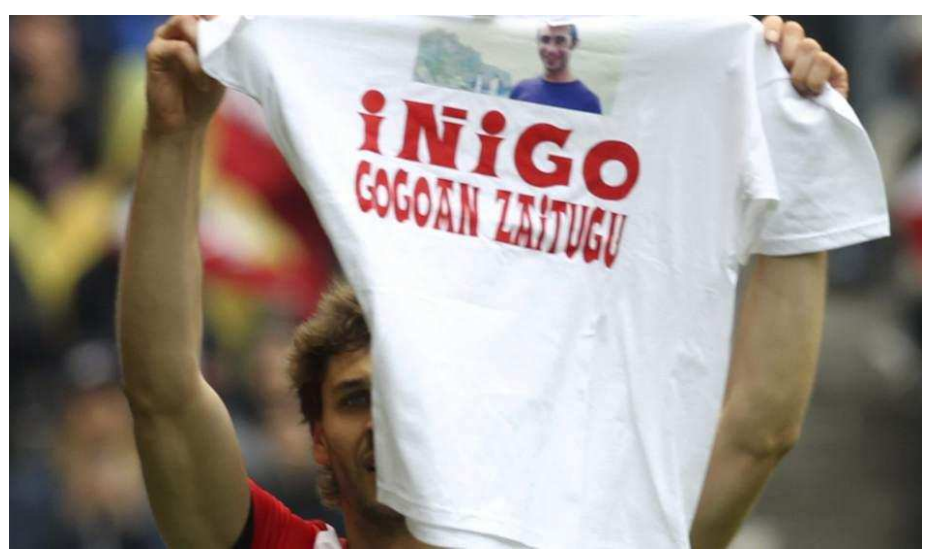

Figura 22. Llorente rinde homenaje a Iñigo Cabacas.

Cuando el Athletic logra títulos (cosa que no pasa desde hace un cuarto de siglo), el estadio se prolonga hasta la ría de Bilbao, el Nervión, y los jugadores la recorren en gabarra (figura 23). El campo se hace mar.

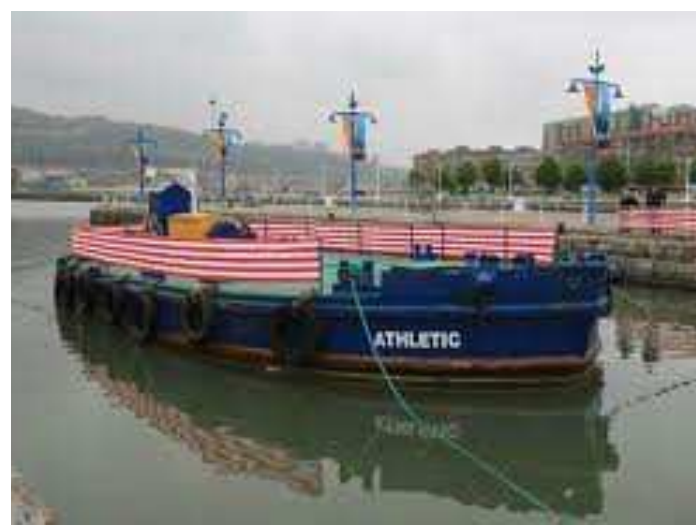

Figura 23. La gabarra del Athletic. 
Cuando va a empezar la temporada, el estadio se prolonga hasta la basílica de Begoña, adonde jugadores y cuerpo técnico acuden por imperativo legal (figura 24). La catedral se hace catedral.

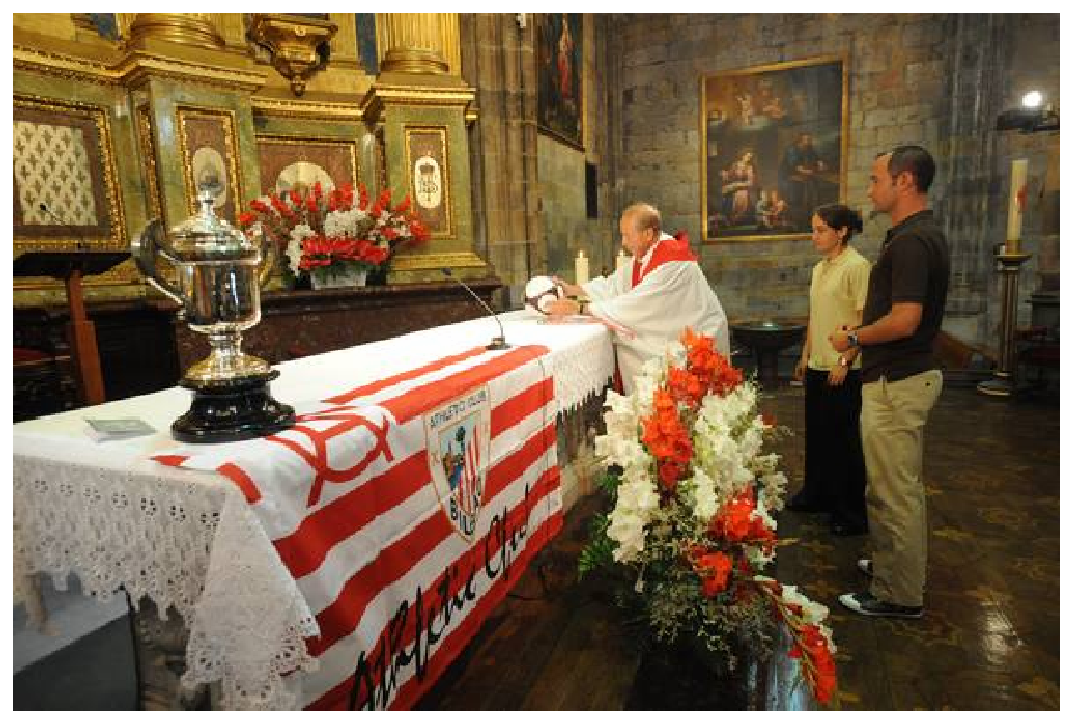

Figura 24. Bendición del Athletic en la basílica de Begoña.

Cuando llegan a San Mamés equipos de postín, se forman inmensas colas para conseguir las ansiadas entradas, y el estadio pasa a convertirse en un gigantesco camping (figura 25).

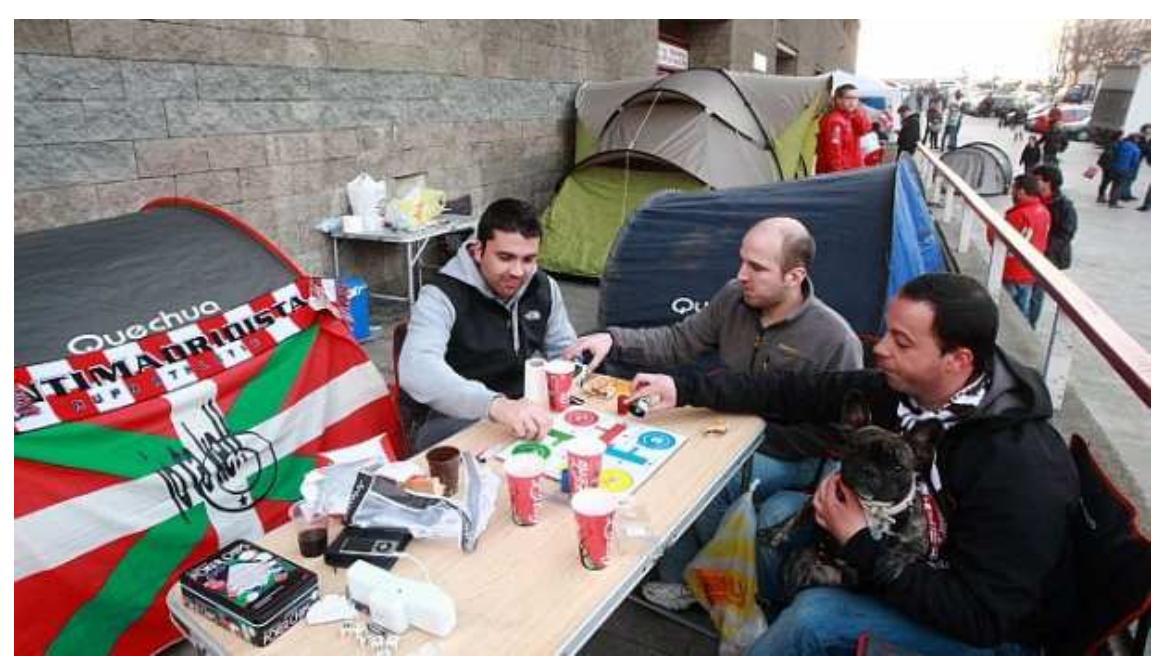

Figura 25. Seguidores del Athletic en la fila para conseguir entradas.

También, como cualquier otro estadio que se precie, puede convertirse en inmensa sala de conciertos donde tienen cabida desde los míticos AC/DC hasta la culé Shakira, pasando por el boss, o sea, buruzagia (figura 26). 


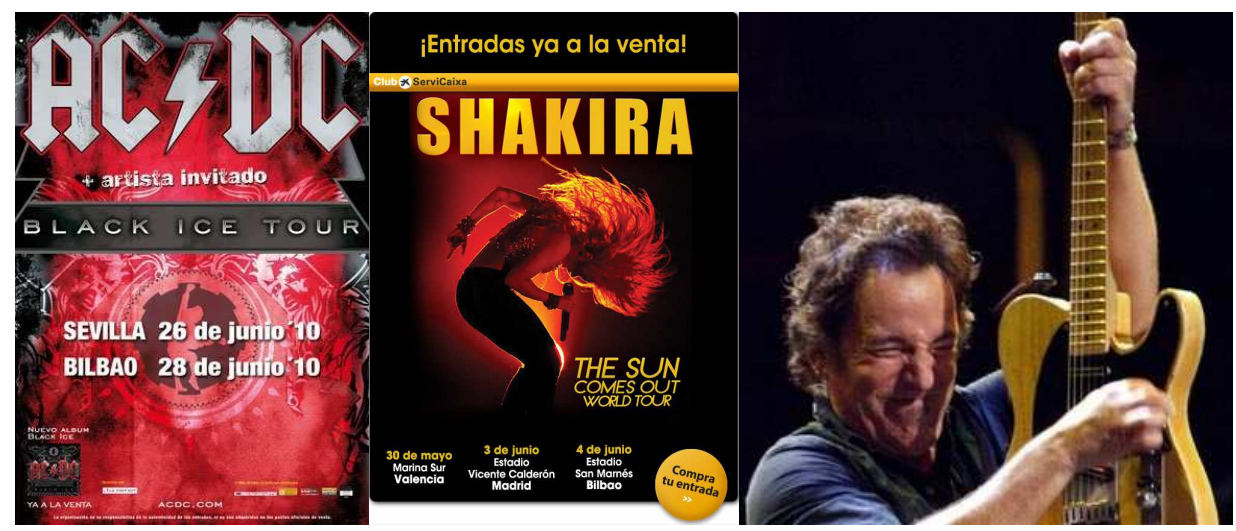

Figura 26. Conciertos en el estadio de San Mamés.

Y, qué mejor forma de acabar este artículo que mencionando al boss. Buruzagia katedralera doa. El boss va a la catedral.

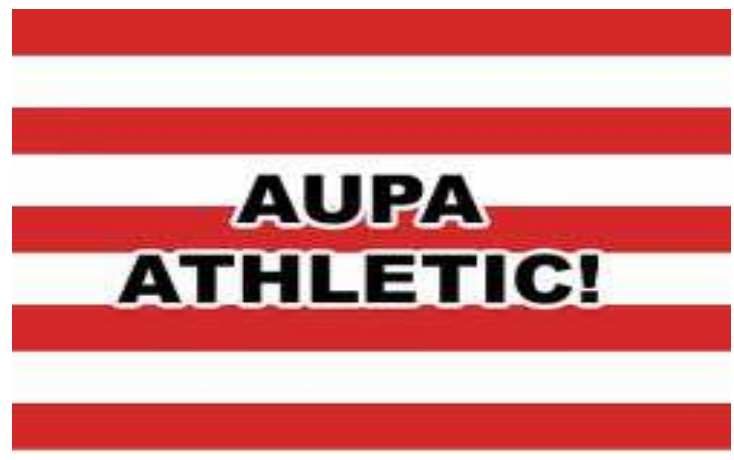

\section{Teatros y museos que cambian de signo: la Bastilla y el Louvre}

Pilar ANDRADE BOUÉ

El objetivo de este trabajo es hacer una aproximación a la mitología urbana de dos "lugares" especialmente significativos en esa ciudad de intensa legibilidad que es París: la plaza y antes fortaleza de la Bastilla, al este del casco urbano, y el Louvre, en el centro. Se trata de dos puntos de referencia o "mojones" - por utilizar la etiqueta de Kevin Lynch que todos conocemos (Lynch 1970: 10)- que tienen en común el haber sido durante muchos años símbolos de la realeza francesa. La Bastilla, como es sabido, lo fue hasta 1789, y el Louvre hasta 1870, año en el que los comuneros incendiaron el Palacio de las Tullerías que unía las dos alas de la gigantesca edificación.

Por supuesto, hay en París otros espacios muy significativos, como por ejemplo la torre Eiffel, que tiene un gran "imaginabilidad" de nuevo, en la terminología de Lynch, capacidad para suscitar imágenes vigorosas en los observadores (Lynch 1970: 18)-, pero también tiene algo menos de espesor semiológico, por no haber sido modificada esencialmente en ningún momento. Otros espacios significativos parisinos son el centro Beaubourg, creado ex novo en 
un solar calificado por el ayuntamiento parisino como "islote insalubre", el arco de la plaza de la Estrella, muy cinematográfico y que además es un nudo de comunicaciones estratégico, o la catedral de Notre-Dame, que sigue como la dejaron sus arquitectos medievales y Viollet-le-Duc y su equipo.

Pero si hemos escogido la Bastilla y el Louvre es porque se trata de dos lugares que han sufrido intensas y relevantes modificaciones a lo largo de la historia, y han cambiado singularmente su aspecto y significación. Esto los ha transformado en lugares mestizos, con inmensas posibilidades de reinterpretación por la complejidad semiológica que implican tanto la densa remodelación histórica como la sintaxis entre su uso y su decorado.

En el caso del Louvre, la pirámide de vidrio encajada en el patio en 1989 suscita la ensoñación del turista o de quien la contempla, y proyecta, por un lado, hacia las antiguas civilizaciones, pero por otro también, hacia el futuro de las posibilidades arquitectónicas. De ese modo, la pirámide ha resemantizado (además de "refuncionalizarlo") el palacio: ¿Se trata de un injerto moderno que el conjunto señorial vetusto expulsa como una espinilla de su seno? (figura 1 ).

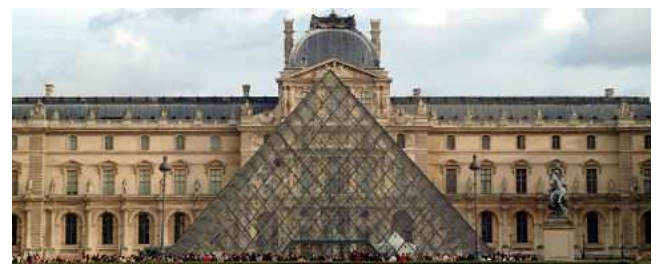

Figura 1. Pirámide de vidrio del Louvre parisino.

¿O por el contrario tiende un puente a los orígenes, como símbolo de poder que es? (figura 2). (Recordemos que existió un plan de Napoleón I consistente ya en edificar en este lugar una pirámide de piedra para celebrar su Imperio).

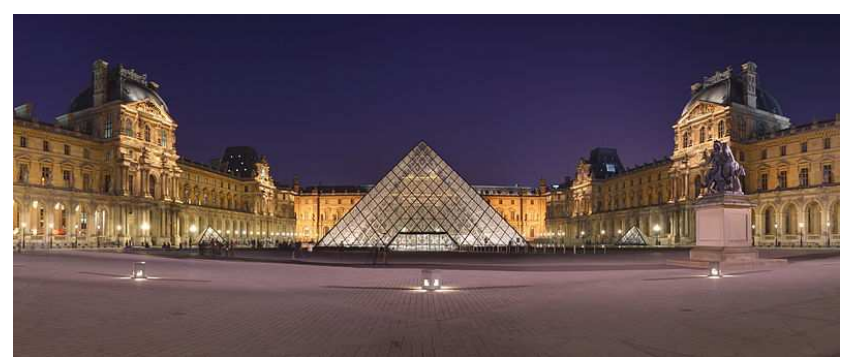

Figura 2. Vista panorámica de la pirámide y el palacio.

¿O bien hace visible en un punto urbanístico crucial los poderes del mal? Una leyenda urbana afirma que la pirámide está hecha de 666 placas de vidrio, el número de la Bestia... La forma mágica perfecta de este volumen geométrico ha llevado igualmente a hablar del "aura" de la pirámide, y hay quien dice sentir, al contacto con el 
cristal, extrañas presencias, y visualizar imágenes de los constructores y de deidades egipcias (figura 3$)^{2}$.

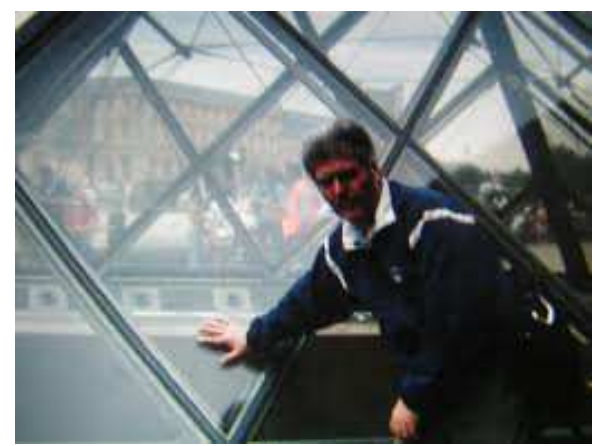

Figura 3. La pirámide manda mensajes de su pasado.

En fin, con ocasión de la celebración de sus veinte años de construcción (abril de 2009), Jenny Holzer operaba una nueva redensificación semiológica: si la pirámide era ya texto (monumento descifrable), se convertía ahora en soporte de otro texto (figura 4).

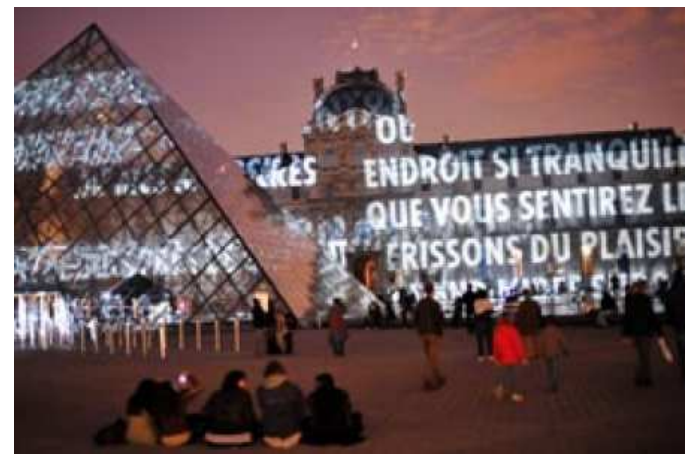

Figura 4. Escritura sobre escritura: ceci ne tuera pas cela.

Pero si el Louvre se ha convertido en mito $^{3}$, más aún lo ha hecho la Bastilla, para la cual las reinterpretaciones son infinitas. Hoy en día, la expresión "tomar la Bastilla" se emplea como sinónimo de "ganar", especialmente si se habla de un acontecimiento que se desarrolle en Francia (por ejemplo un evento deportivo) o que tenga connotaciones políticas de izquierda (deseo de un cambio de gobierno, vgr.).

Lo cierto es que en 1789, la demolición de la fortaleza situada en la actual plaza durante la Revolución Francesa la transformó, de

2 Cf. la página web: http://michelgenovese.unblog.fr/category/les-enigmes-dulouvre-d-etrange-presences-phantomatiques/ (Genovese 2010). El Louvre ya tenía sus propias leyendas: el demonio asirio Belphégor se paseaba por los corredores. Novelas y producciones audiovisuales se hicieron eco naturalmente de este otro mito.

3 En sentido barthesiano: "Tout peut être un mythe, qui est susceptible d'un discours" (Barthes 1957: 193). 
bastión y símbolo de la tiranía absolutista, en 1) lugar de peregrinación en que se conmemoraría el Pueblo, con mayúsculas, y 2) atracción turística (las supuestas piedras de la fortaleza destruida se vendieron durante décadas como hoy los restos del muro de Berlín (figura 5). La primera connotación se mantiene hasta nuestros días, y la segunda se ha mitigado mucho por impericia quizá de los arquitectos, que tras varios intentos no supieron proyectar un edificio con entidad estética suficiente para atraer al visitante, como veremos.

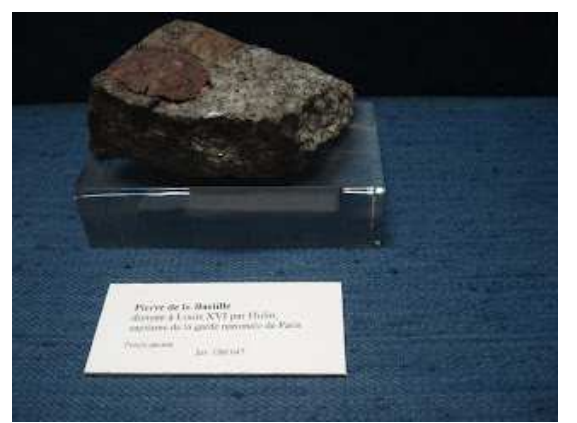

Figura 5. Piedra de la Bastilla conservada en el Museo de Carnavalet.

En los años que siguieron a la demolición de la fortaleza, muchos soñaron con volver a celebrar en esta plaza el poder real o imperial. Napoleón concretamente trató de erigir en ella una gigantesca fuente en bronce con forma de elefante, tanto para escarnio de los españoles, cuyos cañones serían el material constructivo, como por dejar un nuevo testimonio (recuérdese la pirámide) de ese sueño de oriente muy francés pero que el corso Bonaparte también hizo suyo ${ }^{4}$. Y efectivamente un elefante de cartón piedra presidió durante cierto tiempo la plaza, siendo, eso sí, progresivamente colonizado por las ratas de un París bastante antihigiénico a la sazón. La Bastilla (nombre que desde entonces lógicamente designó la plaza) volvió no obstante, a su destino revolucionario en 1846, y por tanto quedó resemantizada del modo en que había previsto la Asamblea Legislativa en 1792: con una alta columna que sostenía en lo alto una estatua de la libertad; la Bastilla era ya símbolo del Pueblo soberano. Y hoy sigue siendo el punto de encuentro privilegiado de todos aquellos que, o bien investidos del poder popular, reivindican algo (figura 6 ):

\footnotetext{
${ }^{4}$ Los elementos orientales engastados en la historia de la Bastilla no terminan ahí. Por un lado, en 1793 se instaló la "fuente de la regeneración", de estilo neoegipcio, construida en yeso y cuya existencia fue efímera. Por otro lado, actualmente los cuerpos de los revolucionarios de 1830 reposan en la base de la columna junto a algunas momias egipcias; porque en 1848, al desenterrar estos cuerpos en el jardín de la Biblioteca Nacional, se cogieron también por error las momias, que habían sido depositadas ahí para evitar su descomposición. RIP.
} 


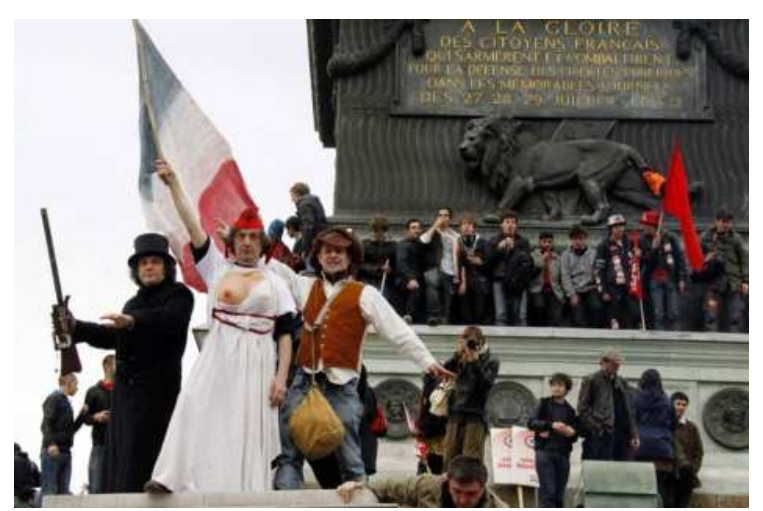

Figura 6. Toma simbólica de la Bastilla por los seguidores de Jean-Luc Mélenchon, candidato de izquierda a la Presidencia de la República francesa (mayo de 2012). Los asistentes a este acto querían conmemorar el aniversario del levantamiento de la Comuna de París en marzo de 1871.

o bien quieren manifestar su solidaridad con marginalidades, víctimas, etc. (figura 7).

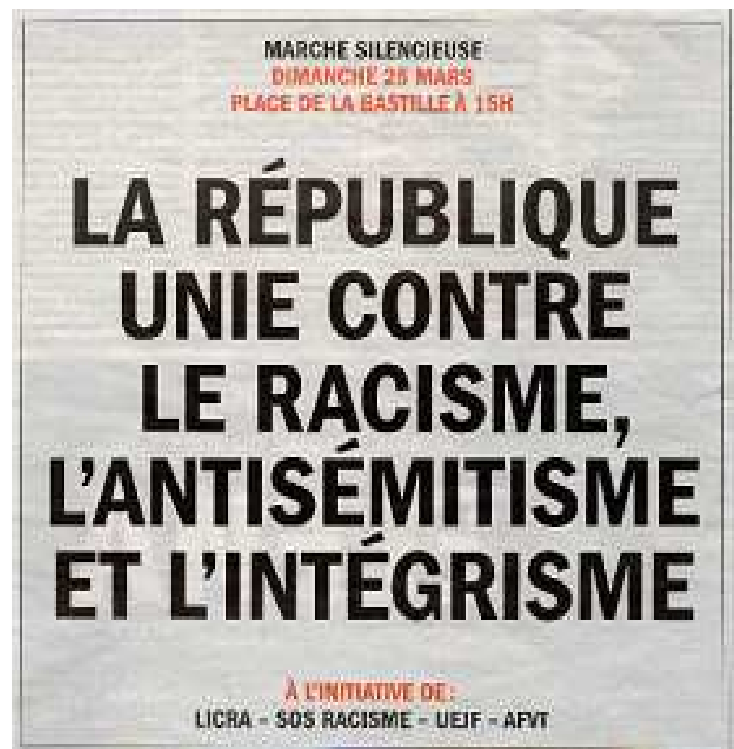

Figura 7. Anuncio en la prensa de la recientísima marcha silenciosa hasta la Bastilla para protestar contra los asesinatos perpetrados por Mohamed Merah (Le monde, 21 de marzo de 2012).

Todo esto ocurre paradójicamente al lado de otra edificación, construida entre 1984 y 1989 en la plaza, que todavía hoy exhala aromas de aristocracia: la Ópera, la nueva ópera de París; es, como se sabe, un edificio ultramoderno diseñado por Carlos Ott y construido algo apresuradamente (como lo demostraron una rápida degradación y diversos malfuncionamientos), aunque el resultado final sea impecable. Este texto arquitectónico de connotaciones altoburguesas se incrusta pues en un lugar leído como símbolo obrero 
- pero lo hace armónicamente y sin discordancias. De hecho, la tan posmoderna combinación de lo socialmente bajo y alto da lugar a espectáculos formidables, como el que contemplaron los ojos de los parisinos el año 2011 con ocasión de la manifestación de los indignados. En la imagen reproducida a continuación (figura 8), los indignados protestan en primer plano y al fondo, Wagner avisa de que estamos asistiendo al "Crepúsculo de los dioses"... ¿financieros? Todo el mundo lo interpretó como una premonición -que parece no haberse cumplido aún.

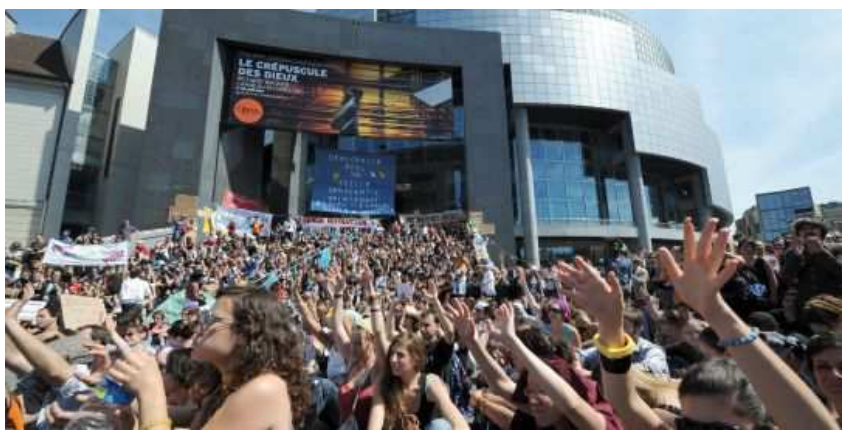

Figura 8. Los indignados parisinos se manifiestan en la plaza de la Bastilla (mayo de 2011).

Pero además en este lugar mestizo por excelencia, las artes, el alimento estético, se codea todos los sábados con el alimento material: el bulevar Richard Lenoir, que desemboca en la plaza, acoge un estupendo mercado y transfiere al entorno el mitema del vientre parisino (figura 9).

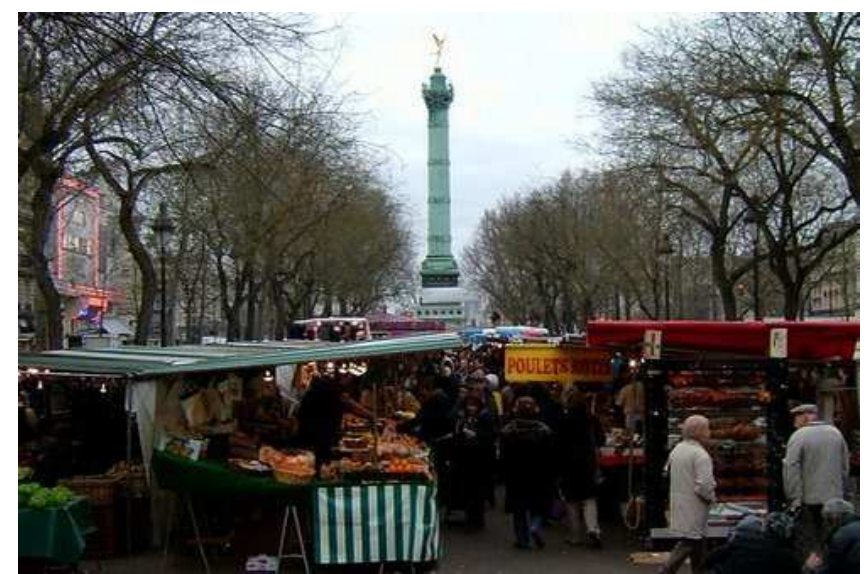

Figura 9. Otro vientre de París: el mercado de la Bastilla.

Para terminar, señalemos que muchos establecimientos, programas informáticos o grupos musicales han tomado el nombre de "Bastilla": sólo en París, existe un teatro, un restaurante, un cine, una tienda de puertas y ventanas, otra de fotografía, y varios hoteles llamados "La Bastille"; la etiqueta ha migrado también a un restaurante de Zaragoza. Además, reciben esa denominación un 
portal de Internet dedicado a difundir videoclips, un sistema operativo de Linux para proteger contenidos, y un grupo musical británico. Por otra parte, en el momento en que se escriben estas líneas se está representando en el Palacio de los Deportes de París un grandioso musical llamado Los amantes de la Bastilla y situado en la época de la toma de la fortaleza: los franceses no se cansan de volver a su mito revolucionario fundacional. En fin, el propio buscador Google ha hecho un doodle conmemorando la toma de la Bastilla (figura 10).

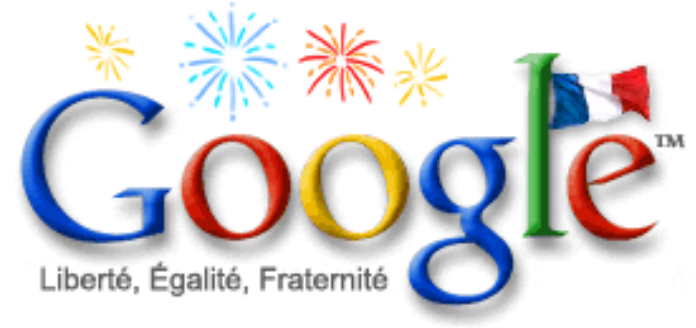

Figura 10. Doodle de Google dedicado al 14 de julio de 1879, confeccionado el 14 de julio de 2001.

Todos estos elementos siguen ayudando a consolidar el mito bastillano y demuestran la vigencia de una memoria histórica y el dinamismo de una resemantización constante de este lugar sagrado.

\section{El Louvre y la Bastilla: de los edificios a la mitificación de los lugares}

Miguel ETAYO GORDEJUELA

El Louvre y la Bastilla fueron dos castillos medievales mandados erigir, no por casualidad, por el rey de Francia en París, ciudad marcada a lo largo de su historia por el pesado intervencionismo del poder estatal en detrimento de su autonomía municipal (Harvey 2008: 299). En ambos edificios se sucedieron usos variados, épocas de abandono, fiestas, pero también matanzas, y los dos sufrieron en algún momento el asalto del propio pueblo de París. Su origen estuvo en las defensas de aquella ciudad. 

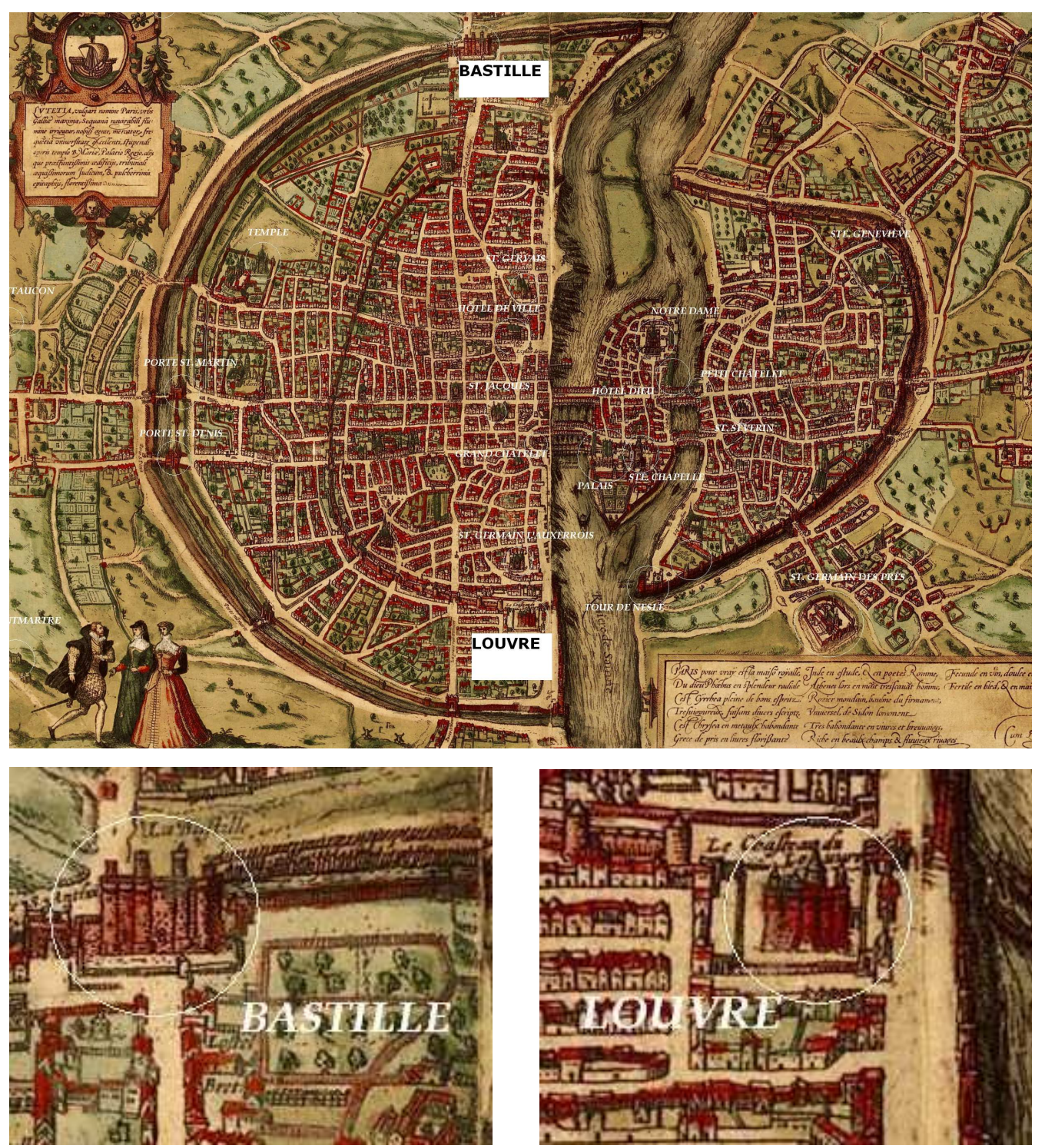

Figura 1. Plano de París de Braun, publicado en 1572 pero que reproduce el aspecto de París hacia 1520, puesto que todavía está en el centro del Louvre el alto donjon donde se guardaba el tesoro real, que Francisco I derribó en 1529.

Todos sabemos que uno de ellos existe todavía, aunque nada quede a la vista de su aspecto primitivo, ya que lleva siete siglos creciendo y transformándose para sobrevivir: el Louvre llegó a ser el mayor palacio real del mundo y combina, a escala gigante, el modelo de palacio italiano cuadrado, en torno a un gran patio central (como el Palazzo Strozzi) y el del hôtel francés con cour d'honneur rodeado por tres alas, como pudiera ser el Hôtel de Ferrare (Müller y Vogel 1985: 456). 


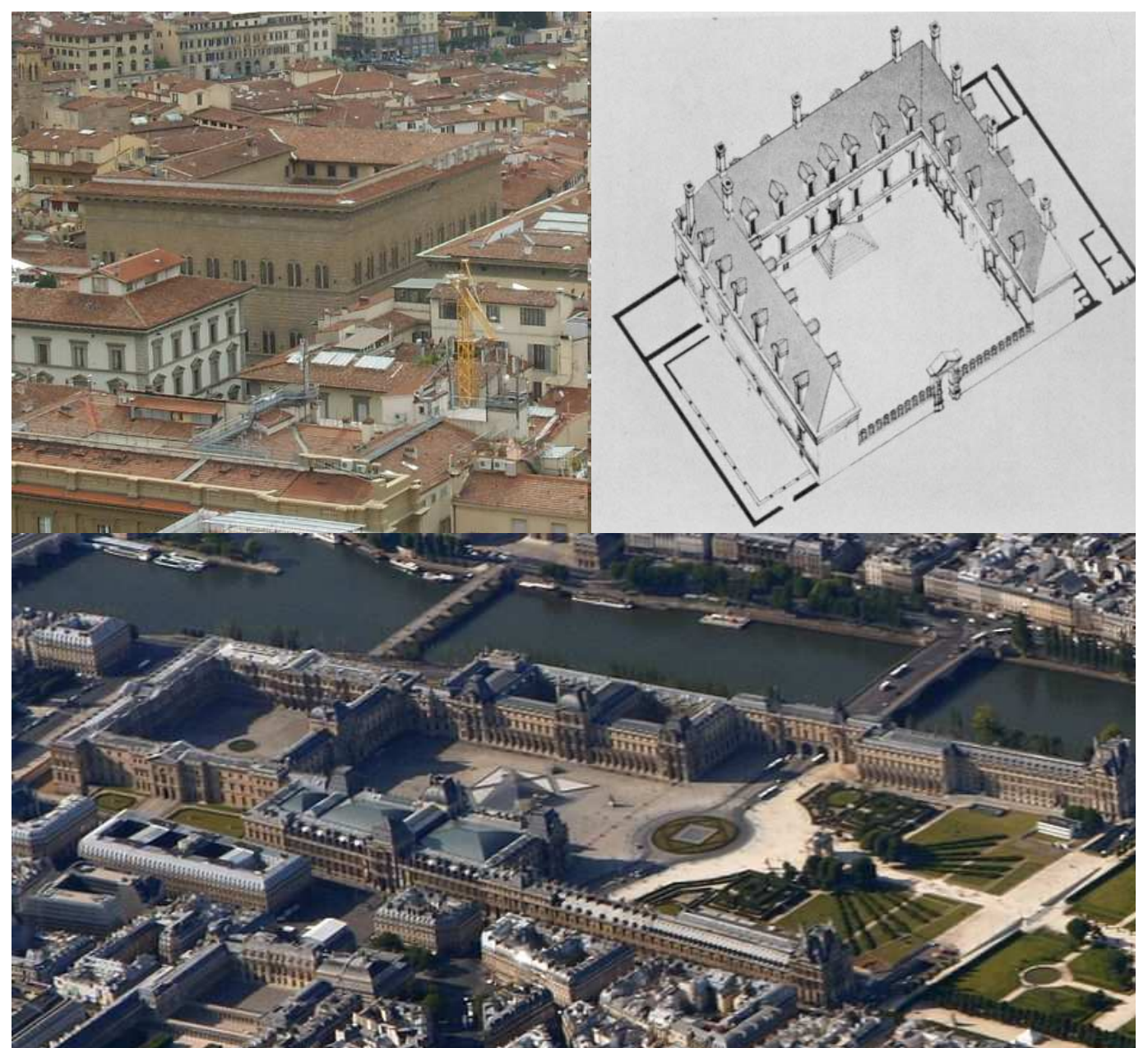

Figura 2. A) Palazzo Strozzi (Florencia); B) Reconstrucción del Hôtel de Ferrare (Fontainebleau); C) Vista actual del Louvre.

La Bastilla, en cambio, mantuvo durante cuatro siglos su aspecto original encastillada entre sus ocho torres y altas cortinas de tres metros de grosor, una verdadera bastille adelantada al recinto amurallado, a la manera anglonormanda, según Viollet-le-Duc (1867: 166). La coronaban unas plataformas adecuadas al uso de la artillería de la época, bombardas todavía de tiro parabólico, lo que aconsejaba emplazarlas en una posición dominante. Siempre igual a sí misma, según atestiguan las miniaturas de Fouquet de las Grandes Crónicas de Francia y de las Horas de Etienne Chevalier (siglo XV), el plano de Bale, del siglo siguiente, o el de Turgot, ya del XVIII, numerosos grabados modernos y las pinturas de la época de la Revolución (las de Robert entre las más conocidas), fue derruida hasta su base, como la odiada Cartago, durante la Revolución Francesa. Ante tanta documentación gráfica, que también encontramos, y más rica todavía en el caso del Louvre, imposible de citar aquí ni menos reproducir, no se comprende que Eric Hazam (2002: 428) se queje de la pobreza de imágenes de París, según él históricamente poco interesada en hacerse retratar. 


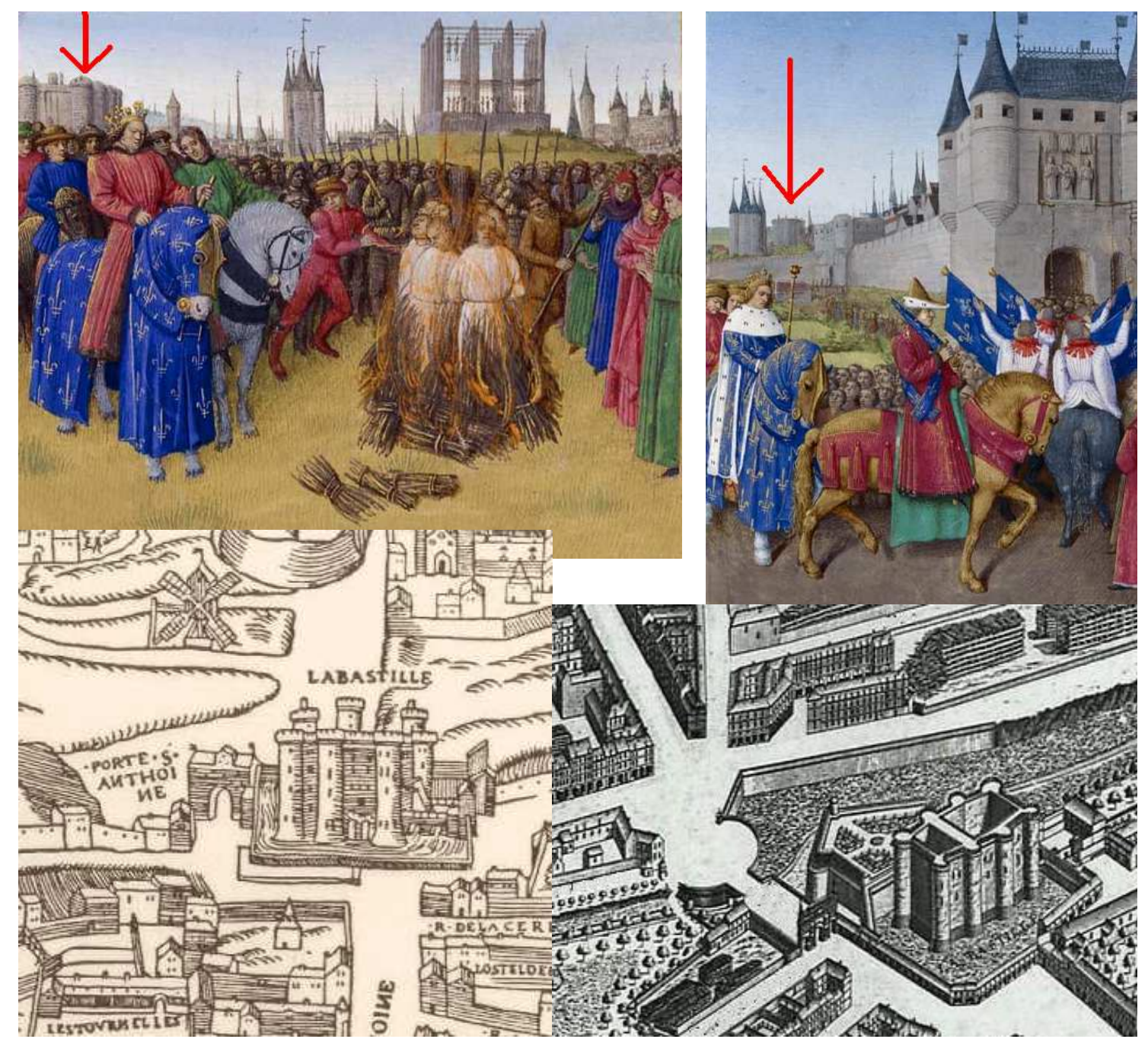

Figura 3. A) Fouquet, Suplicio de los discípulos de Amaury de Chartres (además de la Bastilla, vista desde el norte, se ven el Temple y el patíbulo de Montfaucon); B) Fouquet, Entrada de Carlos $V$ tras su coronación en Saint Denis (más allá de la puerta del mismo nombre se ven la de Saint Martin, el Temple y la Bastilla, a lo lejos); C) Plano de Bale (1532); D) Plano de Turgot (1776).

El castillo del Louvre formaba parte de las imponentes fortificaciones levantadas desde finales del siglo XII por Felipe Augusto: frente a la Torre de Nesle, situada en la orilla izquierda, defendía la ciudad junto al río aguas abajo: todavía en un grabado del siglo XVII vemos aquella novelesca torre de Nesle haciendo pareja con la de la Conférence, aneja ésta al viejo castillo del Louvre, y que sobrevive, a pesar del avance hacia el oeste de la galería que conectaba con las Tullerías. 


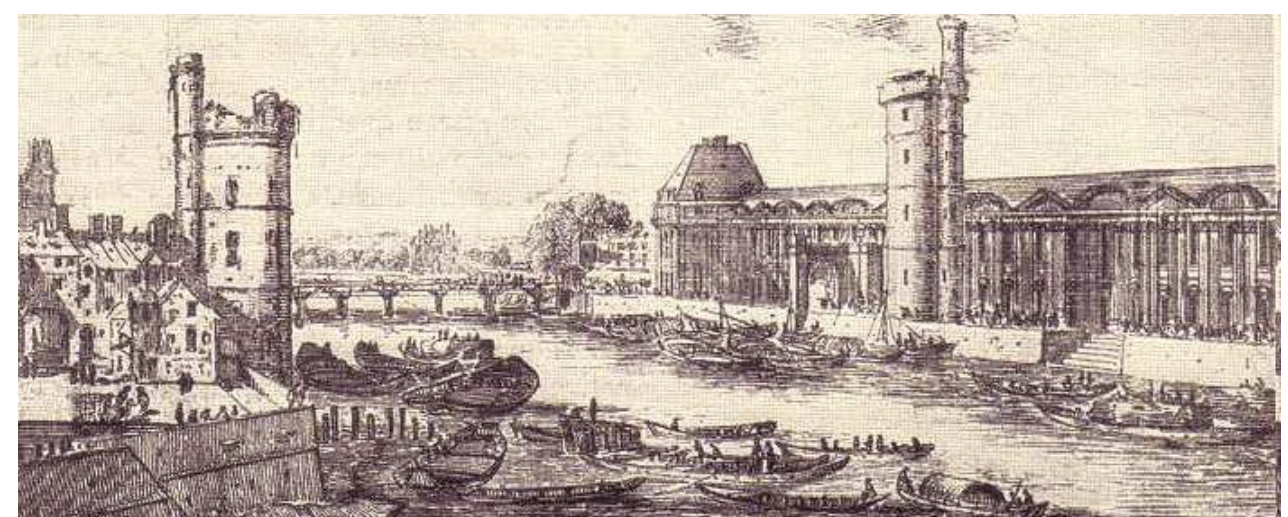

Figura 4. Vista del Sena aguas abajo en un grabado del siglo XVII.

Unas gruesas cadenas cruzaban el Sena en la otra parte de la ciudad, aguas arriba, y completaban el dispositivo que protegía París por la entrada y salida del río. En los dos siglos siguientes la orilla derecha se desarrolló tanto que el recinto amurallado se quedó estrecho: uno nuevo, el de Carlos V, amplió a finales del siglo XIV aquella parte. La fortaleza de la Bastilla se levantó entonces para defender la Puerta de San Antonio, al este, mientras que al oeste el castillo del Louvre quedaba dentro del nuevo recinto y perdía su primitiva función militar. Esta situación se mantiene todavía en el magnífico plano de Braun con que empezábamos (figura 1). Veamos uno y otro edificio.

Este es el conjunto del Louvre en el momento de su máxima expansión en superficie (figura 5), antes del incendio, durante la Comuna (1871), de las Tullerías, el ala que cierra la inmensa explanada por el oeste, a la derecha de la imagen, y que ya no existe.

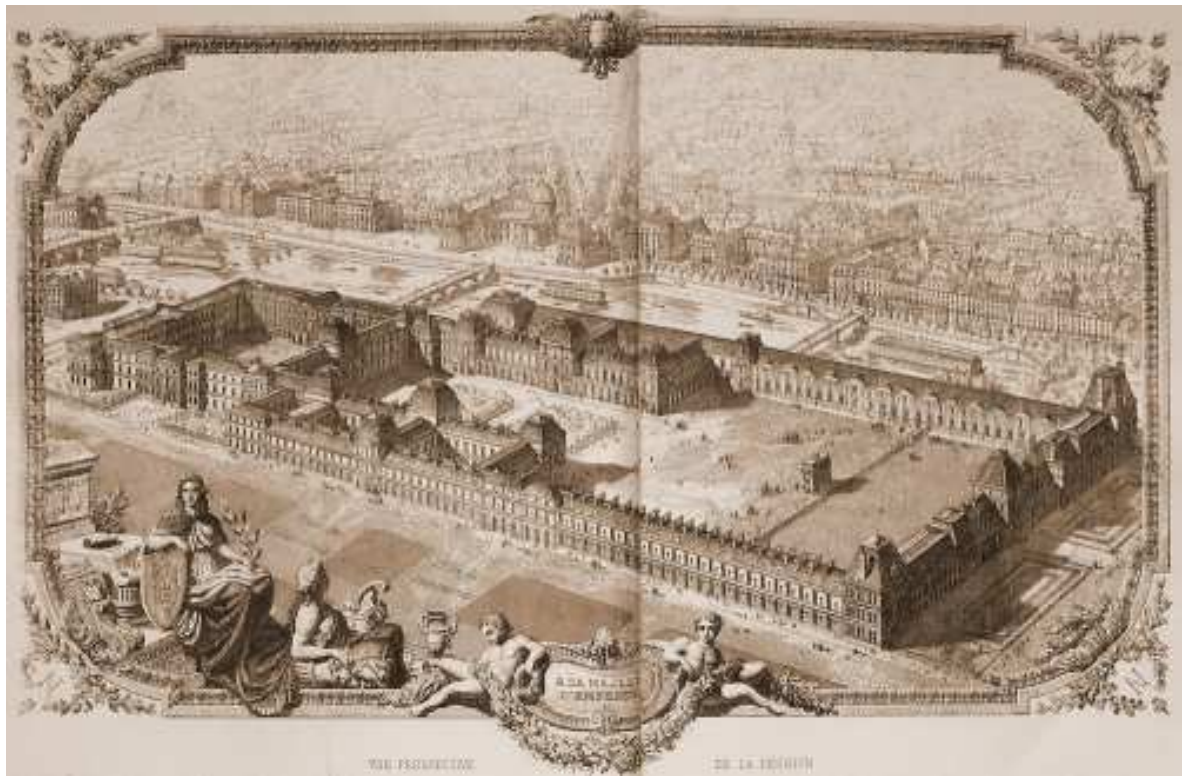

Figura 5. El Louvre a vista de pájaro desde el noroeste, en un grabado del II Imperio. 
El Louvre de Felipe Augusto fue un rudo castillo feudal cuadrado con torres en los ángulos y fosos, necesarios puesto que estaba en llano, y una alta torre cilíndrica exenta dentro, el donjon de 30 metros de alto, rodeada de un foso y accesible por un puente levadizo. El donjon ocupaba el centro de un patio cuya superficie no llegaba a la cuarta parte de la actual Cour Carrée (que se ve a la izquierda de la imagen precedente). Había además dos edificios con aposentos adosados a las murallas oeste y sur, como era usual. La muralla oeste era especialmente fuerte, por ser la más amenazada al ofrecerse al exterior de la ciudad, cuya principal amenaza era entonces el vecino Estado anglonormando. Felipe Augusto, que siguió residiendo en el palacio real de la Cité, en la misma isla que la catedral, alojó en el Louvre su tesoro, archivos y arsenal.
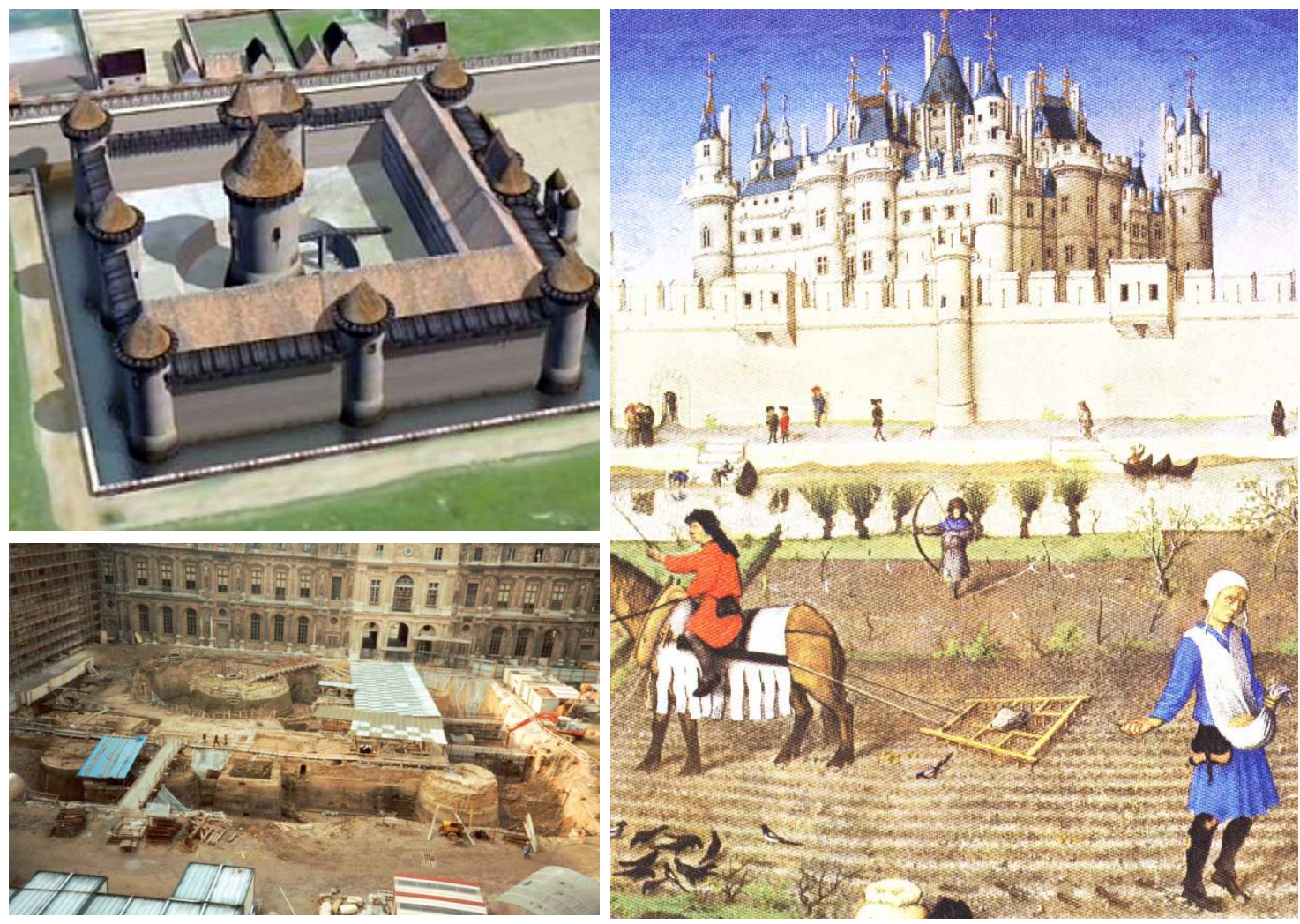

Figura 6. A) Reconstrucción del primitivo castillo; B) Excavaciones en el ángulo suroeste de la Cour Carrée, donde se aprecia la base circular del donjon, al fondo, y las de los cubos de la muralla, un poco más cerca; C) Hermanos Limbourg, Octubre, en Las Muy Ricas Horas del Duque de Berry, vista tomada desde la propiedad de éste, el Castillo de Nesle (Longnon y Cazelles 1989: 179), con el Sena de por medio.

Fue Carlos V, cuando dos siglos más tarde adelantó las murallas hacia el oeste en aquel sector, quien lo convirtió en una suntuosa residencia real e instaló en él su famosa biblioteca. Adquirió el aspecto ornamentado que vemos en las miniaturas del siglo XV: las 
de los Limbourg (figura 6.C) y de Fouquet, que no reproducimos aquí (el Martirio de San Andrés, de las Horas de Etienne Chevalier), con sus matacanes en las torres y las ventanas que se abrieron en los aposentos del sur y el oeste, así como en las torres. Es un buen ejemplo de la transición de la fortaleza feudal al palacio que se dio de manera tan fluida en el otoño de la Edad Media (Kubach 1989: 192). Sin embargo los reyes que le siguieron se procuraron alojamientos más cómodos a una y otra orilla del este de París, en el Hôtel de Saint-Paul y en el de Tournelles. De aquel Louvre medieval solo quedan los cimientos, las columnas de la Salle Basse y la base de la muralla oeste.

La transformación del Louvre empieza, tras un siglo sin reformas, con Francisco I, decidido a convertirlo en un verdadero palacio real, quien ordenó cambiar murallas por jardines, derribar la torre central que ensombrecía el patio y que, finalmente, llamó a Pierre Lescot para construir un palacio renacentista. De la colaboración entre el arquitecto Lescot y el escultor Jean Goujon surgiría el ángulo suroeste de la actual Cour Carrée, el embrión de todo el enorme conjunto posterior. Hasta Luis XIV el Louvre iba a mantener estas dos alas renacentistas y las otras dos (las del norte y este) góticas. El palacio del Louvre fue en los siglos siguientes una obra intermitente, imposible de detallar aquí, con parones prolongados por falta de dinero entre otras cosas, con abandonos, cambios de uso, ocupaciones merecedoras de una $k$, amenazas de derribo, asaltos y destrucciones. Pero los principales reyes dejaron en él su impronta, a veces ampliaciones colosales, igual que los faraones en los grandes templos de Egipto, atentos a legitimarse vinculándose a sus ilustres antecesores en un lugar mitificado.

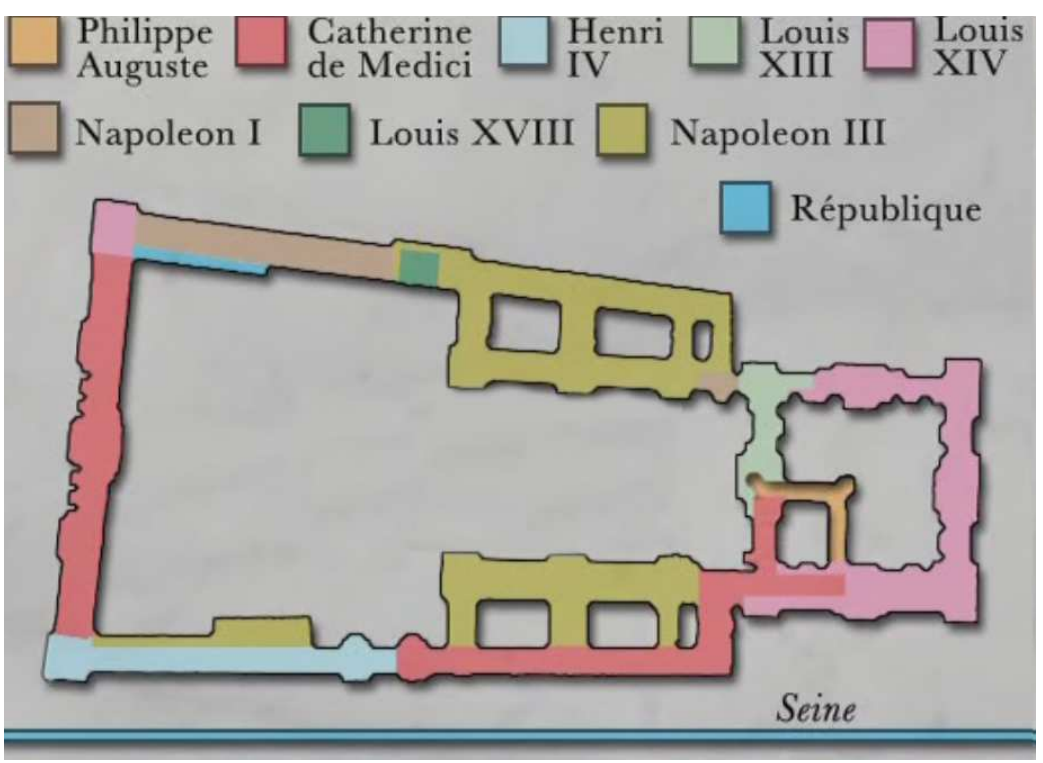

Figura 7. Plano simplificado de las etapas de la construcción del conjunto del Louvre. 
Catalina de Médicis, regente y madre de reyes, decidió, todavía en el siglo XVI, hacerse un nuevo palacio más alejado de París (las Tullerías), a medio kilómetro al oeste del Louvre: allí trabajaron sucesivamente Philibert Delorme y Jean Bullant. Se inició también una larga galería que partía del Viejo Louvre, hacia el Sur, perpendicularmente al río, para doblar enseguida hacia el oeste, siguiendo la orilla, y poder acceder a cubierto al nuevo edificio. Fue Enrique IV, a principios del siglo siguiente, el iniciador de los grandes conjuntos urbanos del París barroco, ese verdadero "escenario para el rey" de que habla Gaussen (2004), quien acabó de llevar la larguísima Galérie du Bord de l'Eau hasta las Tullerías. A él se atribuye el Grand Dessein de lo que habría de ser el Louvre, que se iba a convertir en el foco de la gran expansión axial de París hacia el oeste, la que seguiría por los Campos Elíseos hasta Neuilly.

Luis XIII decidió cuadruplicar la Cour Carrée y encargó a Lemercier el Pabellón del Reloj, que se adaptaba al diseño de Lescot e iba a servir de modelo para los futuros pabellones de Napoleón III. Entretanto se fue a vivir al cercano Palais Royal, conocido con ese nombre todavía hoy, que había sido la residencia de Richelieu. Luis XIV se instaló en las Tullerías, mandó levantar al norte el Pabellón de Marsan, gemelo del de Flore, al otro lado, construyó un gran teatro (la Ilamada "Sala de Máquinas" por su compleja tramoya escénica) y encargó a Le Vau acabar en el Louvre la Cour Carrée. Incluso llamó a Bernini para la nueva fachada Este: como el italiano aconsejara derribar todo lo hecho y empezar de nuevo, fueron los arquitectos de la casa Le Vau, Le Brun y Perrault quienes se encargaron de diseñar la famosa columnata atribuida al último, una fachada grandiosa a tono con el palacio del Rey Sol que, antes de que acabaran las obras, ya había decidido cambiar de escenario y mudarse definitivamente a Versalles, dejando todo empantanado. Los edificios de la Cour Carrée quedaron inacabados, sin techar siquiera, abiertos a la lluvia y los vientos durante casi un siglo. 

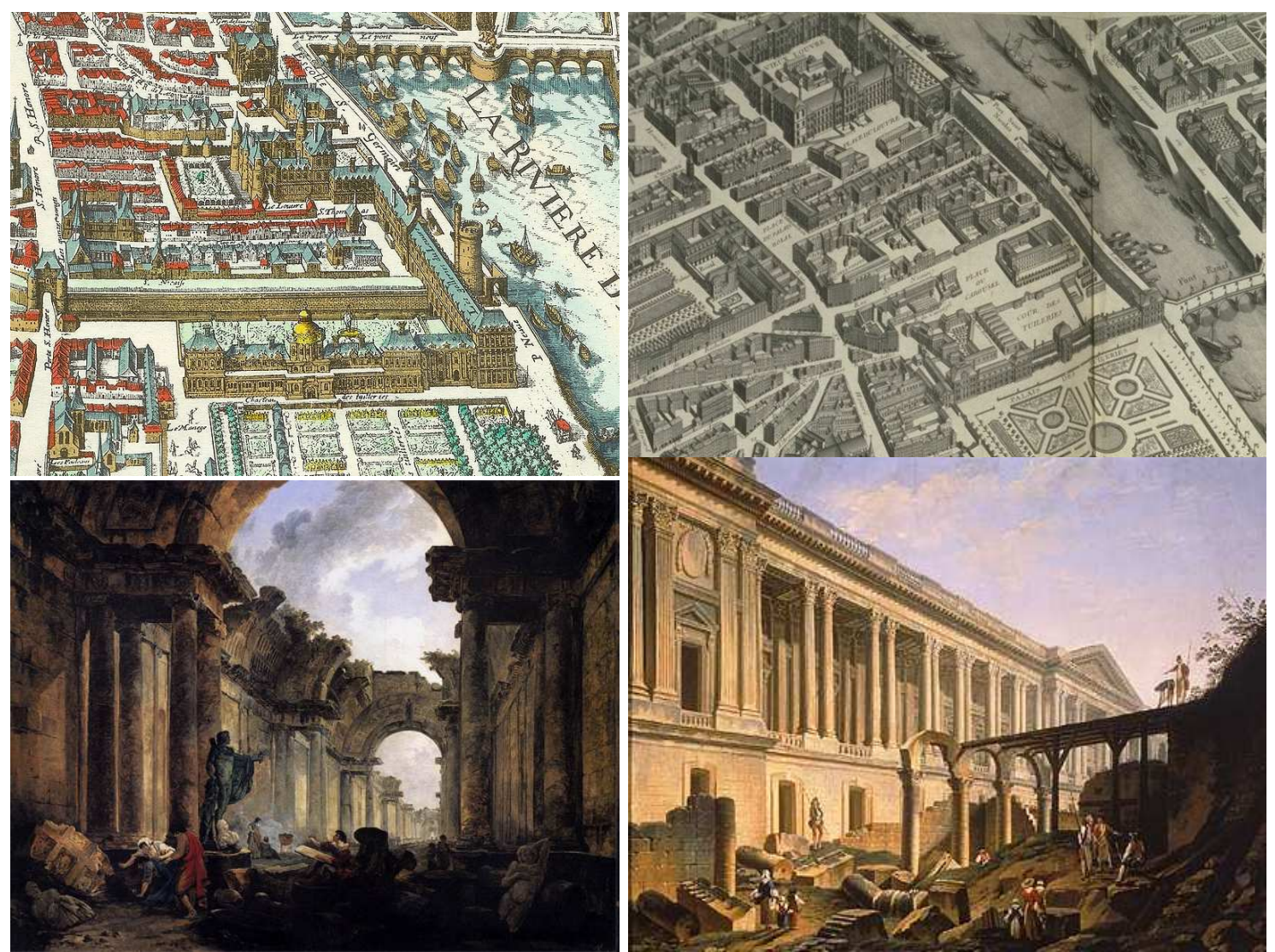

Figura 8. A) Plano de Mérian (1615), todavía con dos alas góticas y dos renacentistas en torno al patio, al fondo; más acá la galería junto al río que enlaza con las Tullerías en el Pabellón de Flore; también se ve, todavía en pie, la torre de la Conférence; B) Plano de Turgot, ya con la Cour Carrée completa; también se aprecia el Pabellón de Marsan, en posición simétrica al de Flore; C) Robert, La Grande Galérie imaginada como ruina; D) Demachy, Derribos en los aledaños de la columnata del Louvre (fachada Este).

El Regente instaló al joven Luis XV en las Tullerías unos pocos años. Se acabaron los edificios de la Cour Carrée y se demolieron las construcciones próximas a la fachada Este, así como las que se habían levantado dentro del patio (figuras 8.A y 8.B). Pero cuando la Corte volvió a Versalles el enorme conjunto quedó dedicado a otros usos e incluso habitado por particulares en régimen de alquiler, reservándose tan solo los apartamentos reales. Se instalaron algunas de las Academias, en la Sala de los Suizos se dieron los primeros conciertos públicos (Concerts Spirituels) y el teatro levantado por Luis XIV fue sede sucesivamente de la Ópera y la Comédie Française. Al exterior se adosaron construcciones improvisadas: tiendas, barracas, etc. En 1750 se llegó a plantear su derribo.

Por dos veces la familia de Luis XVI fue llevada a la fuerza a las Tullerías durante la Revolución: la primera desde Versalles, y la segunda tras su detención en Varennes. Se dieron allí saqueos, la matanza de los 900 suizos a manos de los revolucionarios, el juicio 
contra el rey... Napoleón se instaló en las Tullerías al acceder al consulado y, a partir de entonces, lo hicieron todos los demás reyes. Aún quedaban ingentes obras por hacer: bajo Napoleón, que contó con el arquitecto Fontaine, se levantó el Arco de Triunfo del Carrusel, coronado por los caballos antiguos de la catedral de Venecia; se empezó la Galería Norte siguiendo la nueva Rue Rivoli; se recreció y remató la Cour Carrée. Napoleón III hizo terminar a Visconti y Lefuel la Galería Rivoli y levantar los grandes pabellones que flanquean la Cour Napoléon. Durante la Comuna poco faltó para que el incendio de las Tullerías, símbolo entonces de la tiranía, acabara con todo.
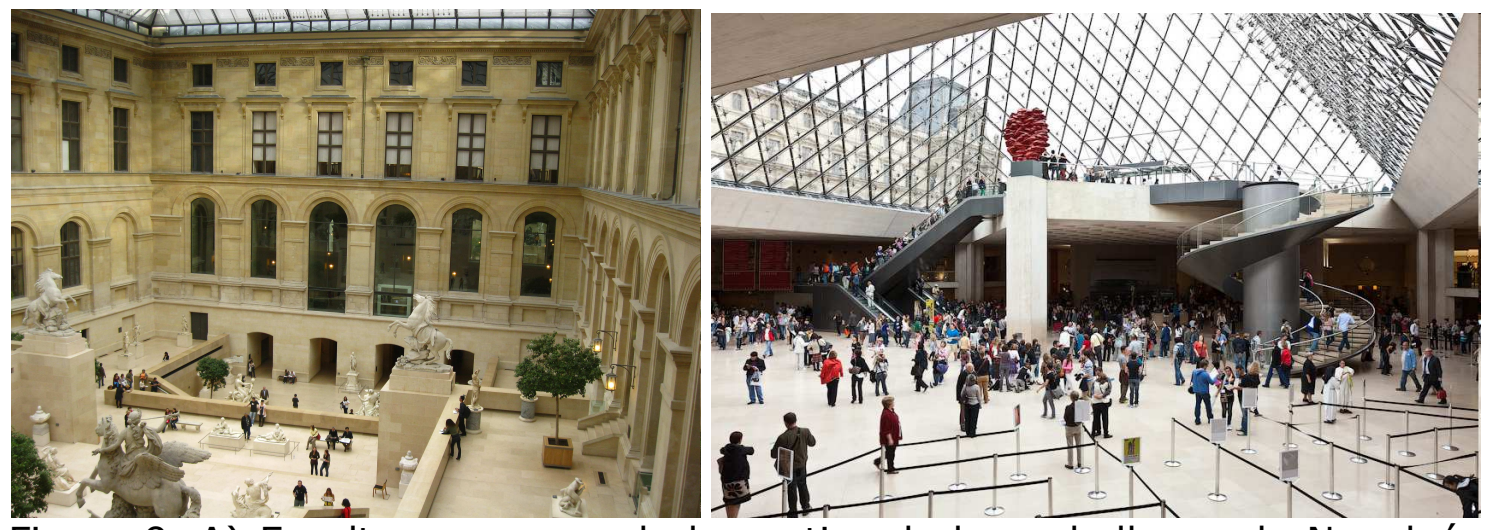

Figura 9. A) Esculturas en uno de los patios de los pabellones de Napoleón III; B) Entrada por la pirámide.

En cuanto al Museo, ya Luis XIV tuvo la idea; Luis XV expuso unos años sus más valiosas pinturas en el Luxemburgo a partir de 1750, pero fue la Convención la que abrió en 1793 al público la Grande Galérie, ese soberbio espacio que recrea Robert convertido en ruinas que emulan las de Roma (figura 8.C), según una moda dieciochesca. Luego vino el Museo Napoleón. La demolición de las ruinas de las Tullerías en 1882 orientó definitivamente el Louvre hacia la función museística. Solo el Ministerio de Finanzas permaneció en el Ala Richelieu hasta la culminación del reinventado Grand Louvre actual. Desde 1989 la pirámide de Ming Pei ha roto el antiguo protocolo palatino y nos lleva directamente al subsuelo, como si de un centro comercial o un intercambiador de transportes se tratara.

Decíamos al principio que la Bastilla, terminada en 1380 no conoce, a diferencia del Louvre, grandes transformaciones hasta su destrucción, salvo las vastas defensas bajas añadidas a su alrededor, para adaptarla a los avances de la artillería. Carlos V vivía al lado en el desprotegido Hôtel de Saint Paul y el castillo le proporcionaba un refugio y una salida segura de París. A las dos torres preexistentes que protegían la puerta de San Antonio, que son las dos exteriores, se añadieron otras seis de 24 metros de altura, unidas por fuertes cortinas. La nueva fortaleza quedaba aislada entre fosos con puentes 
levadizos. El bastillon de tierra del exterior sería ya, probablemente, del siglo XV.

Asediada siete veces a lo largo de su historia, es fama que esta imponente fortaleza se rindió seis. Aunque no llegó a residencia real, allí se divirtió la corte con su rey -cómo no, Francisco I- en suntuosas recepciones y banquetes. Fue después arsenal y cuartel pero Richelieu le adjudicó su definitivo papel como prisión: la Máscara de Hierro, Basompierre, Voltaire, que estuvo un año, Mirabeau, el caballero de la industria Latude, que se fugó por la chimenea, y el marqués de Sade fueron algunos de sus inquilinos más célebres. A este último se lo llevaron a la casa de locos de Charenton justo diez días antes del 14 de julio. Abolidas en 1784 las lettres de cachet, por las que el rey enviaba a prisión a quien quería sin mayores garantías, estaba prácticamente vacía (siete prisioneros sin importancia) el famoso día, cuando su gobernador, el marqués de Launay se rindió, al frente de sus 32 suizos y 82 inválidos: vemos abajo (figura 10.A) su arresto pintado por Lallemand. Tras la Toma de la Bastilla se emprendió su demolición; se tallaron, usando sus piedras, 83 maquetas que se distribuyeron por las provincias, en recuerdo de los horrores del despotismo. El pavimento de la plaza la Bastilla dibuja hoy día parte de su perímetro.

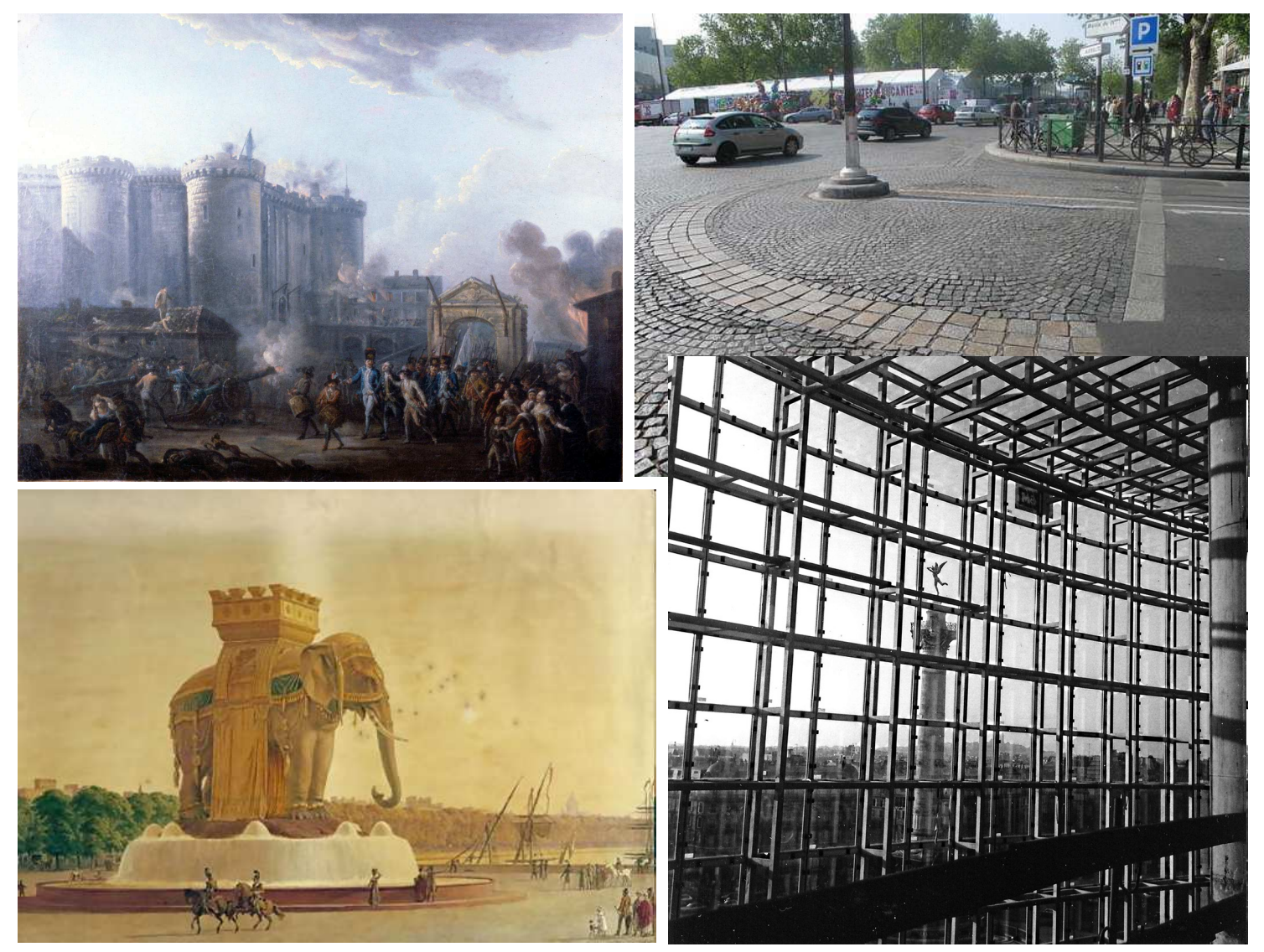

Figura 10. A) Lallemand, Toma de la Bastilla; B) Pavimento de la plaza con el dibujo del perímetro de la fortaleza; C) El elefante de cartón piedra que 
presidió la plaza, en un grabado romántico; D) La Columna de Julio desde la nueva ópera.

En su lugar se abrió una plaza y se instaló la guillotina: 75 ejecutados entre el 9 y el 14 de junio. En el centro se pensó colocar luego una fuente con la forma de un gigantesco elefante cuya maqueta a tamaño real, invadida de ratas, es la guarida del pequeño Gavroche en Los miserables de Hugo. La Columna de Julio que hay hoy en su lugar es el monumento a los más de 500 caídos en 1830, enterrados a sus pies, nuevo holocausto sobre los anteriores en el mismo santuario. Donde estuviera la estación de ferrocarril de la Bastilla, de 1859, al este de la plaza, se posó en 1989, en conmemoración de la fecha mítica (como la pirámide del Louvre), la redonda mole de acero y cristal de la "ópera del pueblo" de Carlos Ott, que ha destronado al ostentoso palacio de la burguesía diseñado por Garnier y vigila de nuevo París por el este, desde lo alto de sus cortinas de vidrio, como una nueva Bastilla de la Confederación de las Galaxias.

\section{Bibliografía}

BARTHES, Roland (1957): Mythologies. París: Seuil.

- (1980): Mitologías. Madrid: Siglo XXI.

BOERIO, Giuseppe (1867): Dizionario del dialetto Veneziano. Terza edizione aumentata e corretta. Venezia: Reale Tipografia di Giovanni Cecchini.

BREWER, Stephen (2006): Venice day by day. New Jersey: Wiley.

CALIMANI, Riccardo (2001): Storia del ghetto di Venezia. Milano: Mondadori, col. Oscar Storia.

- (2002): L'Europa degli Ebrei. Vienna, Praga, Berlino, Parigi e Trieste: Le capitale Europee dell'Ebraismo tra Ottocento e Novecento. Milano: Mondadori, col. Oscar Storia.

CARTARESCU, Mircea (1997): Orbitor. Barcelona: Humanitas.

GAUSSEN, Frédéric (2004): Paris vu par les peintres. París: Odile Jacob.

GENOVESE, Michel (2010): "Les énigmes du Louvre, un grand secret. D'étranges présences fantomatiques", en Une étrange expérience dans la vie d'un enquêteur extrasensoriel, 08/08/2010. En: http://michelgenovese.unblog.fr/category/les-enigmes-du-louvre-detrange-presences-phantomatiques/ [Consulta: 28/09/2012].

HARVEY, David (2008): París, capital de la modernidad. Madrid: Akal.

HAZAM, Eric (2002): L'invention de Paris. Il n'y a pas de pas perdus. París: Seuil.

KUBACH, Hans Erich (1989): La arquitectura románica. Madrid: AguilarAsuri.

LONGNON, Jean; y CAZELLES, Raymond (1989): Las muy ricas horas del Duque de Berry. Madrid: Casariego.

LYNCH, Kevin (1970): La imagen de la ciudad. Primera edición: 1960. Buenos Aires: Infinito.

MÜLLER, Werner; y VOGEL, Gunther (1985): Atlas de arquitectura. Madrid: Alianza. 
VÁCZI, Mariann (2011): "Subversive Pleasures, Losing Games: Basque Soccer Madness". South African Journal of Sociology, vol. 42, núm. 1, pp. 21-36.

VÁZQUEZ MONTALBÁN, Manuel (1988): El delantero centro fue asesinado al amanecer. Barcelona: Planeta.

- (2005): Fútbol: Una religión en busca de dios. Barcelona: DeBolsillo.

VIOLLET-LE-DUC, Eugène (1867): Dictionnaire raisonné de l'architecture française du XIème siècle au XVIème siècle. París: Bibliothèque de I'Institut National d'Histoire de l'Art, Coll. Jacques Doucet.

ZINGARELLI, Nicola (2010): Lo Zingarelli: Vocabolario della lingua italiana. Bologna: Zanichelli.

\section{Filmografía}

CAMPANELLA, Juan José (dir.) (2009): El secreto de sus ojos. Argentina / España: Tornasol Films / Haddock Films / 100 Bares.

FERNÁNDEZ ARMERO, Álvaro (dir.) (2007): Salir pitando. España: Columbia Pictures / Estudios Picasso / Morena Films.

RADFORD, Michael (dir.) (2004): El mercader de Venecia (The merchant of Venice). Estados Unidos / Italia / Luxemburgo / Reino Unido: Movision / UK Film Council / Film Fund Luxembourg.

SPIELBERG, Steven (dir.) (1993): La lista de Schindler (Schindler's List). Estados Unidos: Universal Pictures. 